\title{
You Say You Want a Revolution: Interpretive Communities and the Origins of Islamic Finance
}

\author{
HAIDER Ala HAMOUDI $^{* \dagger}$
}

TABLE OF CONTENTS

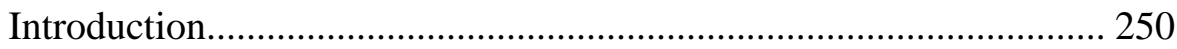

I. Langdellian Formalism in the Islamic Experience................... 259

A. Islamic Langdellianism Defined .................................. 259

B. Islamic Langdellianism in Application ......................... 262

II. Shi' ism's Organizational and Religious Authority .................. 264

A. Shi' ism and the Imamate ............................................... 264

B. Shi'i Religious Authority in the Modern Era ................... 266

1. Principles of Usuli Shi'ism................................. 266

2. The Role of the Mujtahids .................................. 269

3. The Rise of Sadr .................................................. 270

III. The Discovery of Islamic Economics ..................................... 273

A. Conceptions of Economic Order .................................... 274

1. Delineation of Objectives ................................... 274

2. Doctrinal Theory of Economics ......................... 275

B. Neutral Role for Shari'a in a Functional System............ 277

1. Shari'a as Limitation ............................................ 277

2. Shari'a as Signpost .......................................... 278

C. Functional Jurisprudence.......................................... 279

1. Assault on Formalist Hermeneutic ...................... 279

* Assistant Professor, University of Pittsburgh School of Law. I would like to thank Abdullahi An-Na'im, Peter Awn, M. Cherif Bassiouni, Michael Dorf, Mohammad Fadel, George Fletcher, Bernard Freamon, Hoi Kong, Melissa Murray, and the Associates Committee at Columbia Law School for their generous comments and support. Any errors are my own.

$\dagger$ Editor's Note: All Arabic language sources have been translated from the originals by the author. 
2. Role of Choice in Deriving Shari'a ...................... 280

D. Functionalism in Application ....................................... 282

IV. Understanding the Jurisprudential Ideas of Iqtisaduna ............. 285

A. Alternative Approaches to Sadrism................................ 285

B. Shari'a and the Interpretive Community ....................... 287

V. Whither Islamic Finance?..................................................... 290

A. Current Practice ............................................................. 291

B. A Revolution Revised ................................................. 295

VI. Reformed Sadrism in Application .......................................... 300

A. Debate over Universal Banking ................................... 301

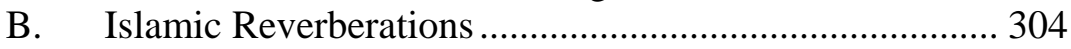

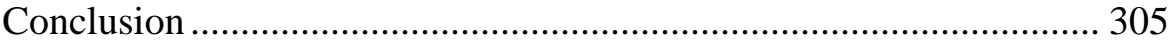

And We have made you into

a community of justice, that you

may be a testament unto humanity. ${ }^{1}$

\section{INTRODUCTION}

Despite its currently conservative character, the modern practice of Islamic finance lies on a bedrock of social, cultural, and economic revolution. $^{2}$ Examination of these revolutionary origins and their attendant jurisprudential implications reveals much about the schizophrenia plaguing Islamic finance today, of a largely formalist practice repeating the functional aims of the early revolutionaries and falsely understood by substantial portions of the wider Muslim community to be achieving such aims. Though the revolution has not come to pass, some of the comparatively radical functional approaches conceived in the context of the anticipated upheaval, in particular those of the Iraqi Shi'i jurist Muhammad Baqir al-Sadr, deserve reconsideration and refinement as a means through which to reformulate the entire practice of Islamic finance in a manner that realizes more completely the aspirations of the broader Muslim community in its call for uniquely Islamic forms of human association in Muslim societies.

1. QUR'AN 2:143.

2. The revolutionaries at issue also embraced goals that were distinctly political, and most commentary concerning them is devoted to their political activity and its resonance among contemporary militant Islamic movements. See, e.g., JOHN L. ESPOSITO, UNHOLY WAR: TERROR IN THE NAME OF IsLAM (2002). However, in keeping with the focus of this Article on Islamic finance and economics, I address primarily the social, cultural, and economic aspects of the revolution and deemphasize its political component. 
The objective of the aforementioned revolution was the radical transformation of Islamic societies based on Islamic Revelation and the establishment of forms of human association grounded in Islamic conceptions of fairness and social justice. This transformation would, it was hoped, result in the creation of a social order that was distinct from the then competing models of the United States, on the one hand, and the Soviet Union and its satellite states, on the other. ${ }^{3}$ There is a deep and venerable tradition within Islamic societies of the study of the body of Islamic rules, norms, and laws developed by jurists, known as the shari'a, as compared with any sort of "Islamic" social science such as economics or history. ${ }^{4}$ As a result, the proponents of the anticipated revolution almost universally approached the subject in distinctly legal terms. ${ }^{5}$ To achieve such radical aims using the law, these advocates required a level of functionality in Islamic jurisprudence that was lacking at the time. The revolution therefore encompassed not only the forms of human association, but, implicitly, the legal means by which they might be achieved; it was, in other words, as much a jurisprudential and legal revolution as it was a social, cultural, and economic one. Among the most prominent of the revolutionaries, both in influence, and, more importantly, in the level of development of his ideas, was Sadr. ${ }^{6}$

\footnotetext{
3. The prominent economist Mahmoud El-Gamal refers to Sadr and two other revolutionary figures, the Pakistani Islamist Syed Abul Al'a Mawdudi and the Egyptian radical Sayyid Qutb, as being responsible for the establishment of Islamic economics. See Mahmoud El-Gamal, "Interest” and the Paradox of Contemporary Islamic Law and Finance, 27 FORDHAM INT'L L.J. 108, 115 n.18 (2003). Each of these individuals manifested their revolutionary ideals in different ways. Sadr was an influential force in the development of Iran's post-revolutionary legal and economic system. See Section II.B.3, infra. Qutb has been an inspiration for a number of militant Sunni Islamic movements. See ESPOSITO, supra note 2, at 8 (describing Qutb as the "father of militant jihad, a major influence on the worldview of radical movements across the Muslim world, and venerated as a martyr of contemporary Islamic revivalism”). Mawdudi called for the overthrow of the secular state and its replacement with a democracy tightly controlled by scholars of Islamic law. NOAH FELDMAN, AFTER JiHAD: AMERICA AND THE STRUGgLE FOR ISLAMIC DEMOCRACY 121-22 (2d ed. 2004).

4. See Joseph Schacht, An Introduction to Islamic LAW 1 (1964) (describing Islamic law as the "epitome of Islamic thought" and "the core and kernel of Islam itself").

5. CHIBLi MALLAT, THE RENEWAL OF ISLAMiC LAW 1-2 (1993).

6. In terms of the development of a specific methodology to achieve their revolutionary economic objectives, Sadr's most prominent contemporaries, Qutb and Mawdudi, are less than comprehensive in their approach to formalism. They make repeated calls for social and economic justice in their work and suggest that such justice can only be realized with the radical transformation of society along Islamic lines, but as to the mechanics of the transformation, much is left vague and imprecise. See Section IV.B, infra. See generally SYED ABUL ALA MAWDUDI, CAPITALISM, SOCIALISM AND IsLAM (Sharif Ahmad Khan trans., Islamic Book Publishers 1977); SAYYID QUTB, AL-'ADALA AL-IJTIMA’IYYAH FIL ISLAM (1st ed. 15th prtg. 2002).
} 
The purpose of this Article is twofold. First, it will expose Sadr's revolutionary jurisprudential approach in developing the notions of commercial order revealed in his seminal work Iqtisaduna, or, Our Economics. ${ }^{7}$ Second, it will demonstrate means by which some of Sadr's radical notions, developed in the context of the theology of Usuli Shi'ism, can be used to make the shari'a a more salutary force in the economic and social order of Muslim states.

The revolutionary, and inherently Islamic, nature of Sadr's notions of economics and commercial order are immediate and obvious. He rejects outright both the authoritarian state control of Soviet-style Marxism and the comparatively unconstrained commercial sphere that is created in capitalist societies in favor of what he describes as an Islamic alternative. ${ }^{8} \mathrm{He}$ is passionately committed to social justice as a norm central to the creation of this Islamic social and economic order. ${ }^{9}$ He takes very seriously the idea that central to Muslim social harmony is the creation of commercial enterprises wherein parties thereto share in the profits and losses thereof equitably, and he is hostile to forms of association wherein one party could conceivably earn a profit while his business partner and fellow believer might, in the context of the same undertaking, suffer a significant loss. ${ }^{10}$ To the modern Muslim mind, this is the source of the concern over the taking of interest and the engaging in speculative commercial activity; namely, that they create the potential for disproportionate losses and gains, and that such disproportionality has the potential to sow enmity and hatred within the community. ${ }^{11}$ Given the near unanimity of Islamic theologians on this matter, it would be fair to say that the entire intellectual movement of Islamic finance rests on such ideas.

Yet Sadr, unlike his contemporaries, developed a theory of jurisprudence that was intended precisely to achieve the articulated goals. ${ }^{12}$ It is

7. See generally MUHAMMAD BAQIR AL-SADR, IQTISADUNA (1977) [hereinafter IQTISADUNA].

8. See Section III.A.1, infra.

9. Id.

10. See Section III.D, infra.

11. See Timur Kuran, On the Notion of Economic Justice in Contemporary Islamic Thought, 21 INT'L J. MidDLE E. STUD. 171, 171-76 (1989) (describing the importance of the mutuality principle among Islamic economists); see also Haider Ala Hamoudi, Muhammad's Social Justice or Muslim Cant?: Langdellianism and the Failures of Islamic Finance, 40 CORNELL INT'L L.J. 89 (2006) (discussing a number of modern, influential Islamic theologians who justify the practices of Islamic finance on the basis of the mutuality principle).

12. Jurisprudential radicalism is only one characteristic of Iqtisaduna. In addition, its ideas on Islamic economics are considerably more comprehensive than any contemporary work on the subject in the same period. As a result, it proved deeply influential to subsequent Islamic econo- 
this kind of methodology, whereby rules are purposefully derived to achieve particular ends that relate to preferred modalities and institutions of human association, that I refer to herein as "functionalism." In employing his functional approach, Sadr called for a "deviationist doctrine" that rejected the then dominant presupposition that the two current objectivist models of capitalism and Marxism embody the sole forms of human association possible in the modern era. ${ }^{13}$ He used the law to delineate the purportedly Islamic alternative. He developed that law in a manner that he admitted was necessarily deeply influenced by his own subjective political and ideological presuppositions towards social justice and mutuality. In so doing, Sadr resembled Roberto Unger's description of the Critical Legal Theorist railing against nineteenth century notions of Langdellian legal science as the perfect expression of a democratic republic and the free market. ${ }^{14}$

Of course, the analogy to Critical Legal Theory is imperfect and incomplete, though some might argue otherwise. ${ }^{15}$ The prominent Islamic studies professor Sherman Jackson raised the possibility that Islamic jurists operate in the overtly political and subjective fashion suggested by Unger despite claiming adherence to the rules of the traditional interpretive system. As I shall explain in further detail below, Professor Jackson's well-articulated work on the inherent manipulability of Islamic doctrine and his comparative efforts with respect to Critical Legal Theory as expounded by Unger deserve immense praise for providing a new means of appraising the development of the shari'a. However, the scope of Jackson's claim, while thoughtful and intriguing, is not terribly constructive for those interested in a more prescriptive approach to Islamic jurisprudence. To repeat the criticisms of Michael Dorf and Samuel Issacharoff concerning what they describe as "radical offshoots of legal realism” in another context, such descriptions may serve to delegitimize the entire notion of Islamic legal or religious doctrine, but, given the implications, they are not helpful in reforming the doctrine to serve the modern community more effectively. ${ }^{16}$

mists, who were willing to adopt some of Sadr's economic ideas without, regrettably, the necessary functional jurisprudential tools that would equip them with the flexibility necessary to address continuing economic challenges. See MALLAT, supra note 5, at 142-43.

13. See generally Roberto Manabeira Unger, The Critical Legal Studies Movement, 96 HARV. L. REV. 561, 567-68 (1983) (noting the false choice between "market and command economies"). 14. See id. at $576-83$.

15. See generally Sherman A. Jackson, Fiction and Formalism: Toward a Functional Analysis of Usul al-Fiqh, in STUDIES IN IsLAMIC LEgAL THEORY 177 (Bernard G. Weis ed., 2002).

16. Michael C. Dorf \& Samuel Issacharoff, Can Process Theory Constrain Courts?, 72 U. COLO. L. REV. 923, 948 (2001) (describing how the "radical realist tradition,” by arguing that all 
As a result, despite the radicalism with which he approached shari'a and his explicit suggestion that its derivation is often an enterprise of political and ideological choice, Sadr himself is deeply concerned with what he calls subjectivity and does not believe that he is engaged in an unbridled exercise of it. ${ }^{17}$ What then to make of him? How to reconcile his easy dismissal of the Langdellian formalism that plagues Islamic doctrine, his willingness to employ radically unorthodox means to achieve new meanings, and yet his abiding concern with excessive subjectivity? Is there a means, in other words, by which Sadr envisions that Islamic legal doctrine might sensibly reform in a manner that permits it to steer safely clear of the Scylla and Charbydis of Langdellian formalism and unbounded subjectivity, where all law descends into politics?

Sadr's particular and uniquely Islamic solution arose within the institutional framework within which he operated. Sadr was an Iraqi Shi'i jurist, born in 1935 to a historic and celebrated clerical family and active from about 1963 until his execution by the regime of Saddam Hussein in April of $1980{ }^{18}$ Given his background and training, Sadr was groomed almost from birth to become a member of the loose network of Shi'i jurists, largely based in Najaf, Iraq, known as the marja'iyya. Pursuant to the doctrine of Usuli Shi'ism, which is the dominant form of Twelver Shi'ism with which this Article is concerned, the marja'iyya is the sole institution with the authority to determine the content of the shari' $a .{ }^{19}$ This authority has been delegated, in a sense, from a lineal descendant of Muhammad known as the Mahdi, ${ }^{20}$ who remains in hid-

law is politics, may serve to delegitimize entirely the Supreme Court as an institution, but could hardly influence the Court's decisions).

17. IQTISADUNA, supra note 7, at 360 ("[A]nd to take the danger of subjectivity seriously...we must look into this matter clearly, and delineate the source of the danger.”).

18. Roy Parviz Mottahedeh, Introduction to MUHAMMAD BAQIR AS-SADR, LESSONS IN ISLAMIC JURISPRUDENCE 28, 31 (Mottahedeh trans., 2d ed. Oneworld Publ'ns 2003) (1978) [hereinafter LESSONS IN ISLAMIC JURISPRUDENCE]. For more information about Sadr's life and work, see also Section II.B.3, infra.

19. Mallat, supra note 5, at 75-83 (describing role of marja'iyya in Usuli Shi'ism). Twelver Shi'ism is the dominant, but not the exclusive form of Shi'ism that exists in the world today. JUAN COLE, SACRED SPACE AND HOLY WAR 5 (2005) (noting rise and ultimate dominance of Twelver Usuli Shi'ism in the nineteenth century). For purposes of this Article, which deals only with Twelver Shi'i doctrine, I use the term Shi'ism to refer exclusively to Twelver Shi'ism and in particular the Usuli version thereof. See generally infra note 74 (noting the origin of the term “Twelver Shi'ism”). For more information concerning Usuli Shi'ism, see Section II.A, infra.

20. There are Sunni references and Sunni movements that have arisen from time to time surrounding the arrival of a descendant of Muhammad known as the Mahdi who has been sent by God to redeem the world. See generally P. M. HOLt, THE MAHDIST STATE IN THE SUDAN 18811898: A STUDY OF ITS ORIGINS, DEVELOPMENT AND OVERTHROW (2d ed. 1970); FERGUS Nicoll, The SWORd of the Prophet, The MAHdi of SudAN AND THE DeAth of General 
ing today and who has a unique link to the Divine that enables him to know God's will with respect to all matters. ${ }^{21}$ The Mahdi's delegation of authority therefore provides to Shi'i jurists operating within the marja'iyya an ability to develop more creative interpretations of foundational text than their Sunni counterparts, who have no comparable theological justification. Sunni jurists are expected to be interpreting text objectively, and any assault on their neutrality in doing so is perceived to be inherently destabilizing in the absence of an authoritative institution. As Professor Jackson has noted, it is precisely this quest for an objective authority in order to defuse debate that has led Sunni jurists to abandon the effort to develop their own interpretations of foundational text at the end of the first millennium, relying instead on the interpretive efforts of their forebears as divided into established schools of thought (madhahib). ${ }^{22}$ With the dissolution of the schools, however, Sunni jurisprudence in the modern era has fallen into a fair level of confusion and uncertainty. ${ }^{23}$ This explains much of the preoccupation in the Sunni Islamic world with codification of supposedly classical rules as a means to assert authority, so that authority is not obtained through institutions or individuals, but rather through the introduction of what are identified, correctly or not, as acceptable classical rules in the framework of the modern nation state. ${ }^{24}$

By contrast, the authority of the marja'iyya to speak for the Mahdi during his hiding remains largely intact and thus when the marja'iyya speaks, it necessarily speaks with authority. It is important to note that the marja'iyya never takes an explicit, uniform position as an institution. Rather, its organizational structure is characterized by a series of informal hierarchies operating in parallel to one another. ${ }^{25}$ Each jurist of sufficient standing runs effectively his own seminary and derives his own shari'a rules largely independently of other jurists. Moreover, the marja'iyya holds no formal meetings nor does it confer any formal sort of membership. However, the immense cultural importance of the institution and the concomitant desire of jurists to remain legitimate to their

GORDON (2004). However, the notion of a living Mahdi currently in hiding who has an intimate connection to God is unique to the Shi'a. See note 21 and accompanying text, infra.

21. Allamah Sayyid Muhammad Husayn Tabataba’', Shi'ite Islam 41, 209-14 (Seyyed Hossein Nasr trans., George Allen \& Unwin 1975).

22. SHERMAN A. JACKSON, ISLAMIC LAW AND THE STATE: THE CONSTITUTIONAL JURISPRUDENCE OF SHIHAB AL-DIN AL-QARAFI 69-79 (1996).

23. Id. at xvi-Xviii.

24. Id.

25. See Section II.B, infra. 
fellow jurists and the broader Shi'i community by not diverging wildly from the competing interpretations of others effectively forces coherence onto the interpretive process. ${ }^{26}$

To Sadr, therefore, the marja'iyya, as an institution, may establish legitimate, neutral and definable bounds to interpretation that distinguish it from purely individualized, subjective political argument. These parameters will undoubtedly reflect ideological and ethical understandings of the foundational texts of Revelation, but within that framework, objective, disciplining rules will emerge to constrain individualized subjectivity on the part of any single jurist engaged in the process of interpretation. Subjectivity and ideological choice in the interpretive process remain possible, but to be credible such choice would necessarily need to lie within the framework established by the marja'iyya at any given time. $^{27}$

Sadr sought to use this theological position to force a change in understanding concerning Islamic jurisprudence among the members of the marja'iyya. Sadr considered the rise of communism among the Iraqi Shi'i community of his time to be a dangerous threat to the social order, and he felt that the formalist obsessions of the marja'iyya, directed primarily at minutiae surrounding rituals of worship, would be insufficient to address that threat. ${ }^{28}$ Sadr therefore sought a particularly and uniquely Islamic alternative to the rising influence of Marxism, in particular, that he hoped would reshape the social, political, and economic order of Muslim societies in a manner that he identified as Islamic and that he traced back to ideals set forth in Islam's foundational text. In order to project his aims beyond the confines of his own subjective analyses and establish the understandings he put forward as being mandated by shari'a, Sadr needed to induce the generally conservative marja'iyya to reassess fundamentally the content of the shari' $a$ and develop a new understanding of foundational text.

Sadr understood and acknowledged this to be a largely political and ideological exercise that necessarily is subjective in its nature. However,

26. Id.

27. An analogy may well exist to American jurisprudence. Owen Fiss, for example, has argued that the judiciary serves a similar role in the American context, effectively bounding in some objective fashion the subjective interpretive process employed by any individual judge. Owen M. Fiss, Objectivity and Interpretation, 34 STAN. L. REV. 739, 744-45 (1982). The idea that the interpretive community creates objective rules is not shared by contextualists such as Stanley Fish, who would argue that the interpretive community merely inculcates its members with particular assumptions, understandings, and biases, rather than providing them neutral bounds within which to operate. Stanley Fish, Fish v. Fiss, 36 STAN. L. REV. 1325 (1984).

28. See Section II.B.3, infra. 
this did not concern Sadr. He believed that objective, neutral, and legitimate limitations would ultimately be placed on the interpretive enterprise to constrain the individual interpretations of the jurists if the marja'iyya as an institution were to adopt his approach in evaluating Islamic jurisprudence and, as the sole authority responsible for deriving the shari'a, redefine it along the lines he articulated. Therefore, much as Professor Fletcher argues that Lincoln effectively introduced a new Constitution in the United States at the close of the Civil War that emphasized equality over liberty by invoking values set forth in the Declaration of Independence, Sadr sought effectively to revisit large portions of the shari'a and recreate it, or rather have the marja'iyya redefine it, as a functional instrument with fairness, egalitarianism, and social justice being among the paramount objectives to be achieved. ${ }^{29}$ Unfortu- $^{-}$ nately, however, much as Lincoln's ideals of formal legal equality lay dormant in the United States immediately after his death due to resistance from the relevant interpretive community, the judiciary, ${ }^{30}$ so has Shi'ism largely ignored Sadr's calls for a reformed jurisprudence despite professed expressions of admiration of him among the Shi'a, as well as from broader sectors of the Muslim world. ${ }^{31}$

Some of the particularities of Sadr's economic and jurisprudential philosophy are grounded in his Shi'i context, but the broader lesson to be learned continues to resonate. Understanding Sadr's revolutionary approach to Islamic economics reveals more starkly the existential problem plaguing the one facet of Islamic economics that continues to survive, Islamic finance. ${ }^{32}$ As noted above, proponents of Islamic finance and Islamic banking repeat Sadr's aims in describing their practice. Sadly, however, they hardly adopt any functional approaches necessary to achieve them.

29. See George P. Fletcher, Our Secret Constitution: How Lincoln Redefined AMERICAN DEMOCRACY 24-25 (2001).

30. See id. at 115 ("Had the United States been able to begin anew, with judges educated in the values and vision of Gettysburg,...Lincoln's prophecy....might have prevailed. [...] Yet, this was not to be the fate of postbellum America.").

31. See, e.g., MALLAT, supra note 5, at 142-43 (discussing the widespread use of and respect for Iqtisaduna in Muslim circles); T. M. Aziz, The Role of Muhammad Baqir al-Sadr in Shi'i Political Activism in Iraq from 1958 to 1980, 25 INT’L J. MIDDLE E. STUD. 207, 218 (1993); Mottahedeh, Introduction to LESSONS IN ISLAMIC JURISPRUDENCE, supra note 18, at 33 (describing Sadr's popularity and influence in Iraq).

32. Olivier RoY, The Failure OF Political Islam 140-41 (Carol Volk trans., Harvard Univ. Press 1994) (1992) (describing the collapse of Islamic economics outside of the finance paradigm). 
With the eventual disappearance of the functionally distinct jurisprudential system that Sadr advocated, Islamic finance has been plagued by formalism, which I define for purposes of this Article in a very limited fashion as the type of logic driven formalism embraced by nineteenthcentury American legal theorists, particularly Christopher Columbus Langdell. ${ }^{33}$ As a result, rather than attempt to develop the distinct means of finance as articulated by the scholarly Muslim community, Islamic financial institutions devote themselves to the creation of elaborate forms of potentially deceptive artifices in order to circumvent prohibitions derived under otherwise unworkable Islamic rules, most importantly those concerning interest on debt and forms of speculative risk. ${ }^{34}$ Islamic finance is thus at present little more than "an almost random patchwork of rules that are neither cohesive nor coherent."35 Religious doctrine serves largely "to obfuscate and complicate at some expense, while simultaneously and disingenuously asserting highly exaggerated claims of equity and social justice."36

Thus, while the dreams of economic revolution may have long faded, the absolute necessity of a jurisprudential revolution has not. As Abdullahi An-Na'im has indicated, unless Muslims are prepared to reevaluate critically their historical understandings of the shari'a, Islam cannot act as a positive force in the lives of Muslims. ${ }^{37}$ In fact, a fairly compelling argument can be made that the shari'a, in the context of finance, acts as a hindrance to the pious by imposing on them senseless transaction costs for no apparent purpose. ${ }^{38}$ Sadr's idea of a transformed and transforming jurisprudence, bounded by objective and neutral rules on interpretive process imposed through the consensus of an authoritative inter-

33. See Section I.A, infra. Obviously, many other conceptions of formalism exist, see, e.g., ANTONIN SCALIA, A MATTER OF INTERPRETATION: FEDERAL COURTS AND THE LAW 23-25 (1997); Ernest J. Weinrib, The Jurisprudence of Legal Formalism, 16 HARV. J.L. \& PUB. POL'Y 583 (1993), but none are relevant for purposes of this Article.

34. Hamoudi, supra note 11, at 91, 94-95.

35. Id. at 95.

36. Id.

37. Abdullahi A. An-Na'im, Islam and Human Rights: Beyond the Universality Debate, 94 AM. SOC'Y INT'L L. PROC. 95, 97-99 (2000).

38. In other contemporary contexts, this same argument that the shari'a acts deleteriously in the lives of at least some Muslims can be made with even more dramatic force. The most notable case concerns the rights of women, where the shari'a as currently developed and applied to varying extents in many Islamic nations imposes and legitimizes a standard of discrimination almost unknown elsewhere in the modern era, with provisions including forced marriage of minors, unequal rights to inheritance, limited opportunities for divorce and heavily discounted values of court testimony. See N.J. Coulson, SuCCession In THE Muslim Family (1971); John L. Esposito, WOMEN IN MUSLIM FAMILY LAW (1982); Donna E. Arzt, Human Rights Law in Islamic States, 12 HuM. RTS. Q. 202 (1990). 
pretive community responsible for redefining foundational text from time to time, is instrumental to the development of a sensible and functional Islamic system based entirely in Islamic doctrine and responsive to the needs of the community.

Part I of this Article will summarize the traditional, formalist Islamic interpretive system employed in Islamic finance today, reveal its similarity to Langdellian legal theory, and further explain how these interpretive principles developed rules governing the modern practice of Islamic finance that strip it of its ability to meet its articulated aims. Part II will then provide context for Sadr's ideas by describing the social, religious, and political context in which he developed them. Part II will also describe Sadr's own background and the nature of his other work both within and outside of the marja'iyya. Part III will set forth in broad outline the revolutionary aims of the economic system described by Sadr and the manner in which functionalism pervades his entire analysis. Part IV will then provide a more complete description of Sadr's jurisprudential notions and their reliance on the robust role of the marja'iyya to redefine the shari'a on the basis of the foundational texts. Part V will describe contemporary Islamic finance and expose the practice as hopelessly formalist. Finally, Part VI will explain how some of Sadr's ideas can be usefully employed in a considerably more conservative capacity to reform Islamic finance along more sensible, functional lines through specific reference to a commercial issue that has been of international interest in the past two decades, namely, the extent to which commercial banks should expand into other financial services activities, most prominently the purchase and sale of securities.

\section{LANGDELLIAN FORMALISM IN THE ISLAMIC EXPERIENCE ${ }^{39}$}

\section{A. Islamic Langdellianism Defined}

The contemporary interpretive trend in the Islamic world is highly formalistic and similar in numerous ways to the jurisprudential theories of Christopher Columbus Langdell in the American context. Where

39. Much of what is written here is a summary of another article devoted to the subject of Islamic formalism in the context of contemporary Islamic finance. See Hamoudi, supra note 11. I wish to emphasize, as I did in the above mentioned article, that my criticisms are directed exclusively to a contemporary manifestation of an interpretive system that claims its origins in Islamic history and not to the rich and varied Muslim jurisprudence of the classical era. Id. at 102-03; see also Haider Ala Hamoudi, Jurisprudential Schizophrenia: On Form and Function in Islamic Finance, 7 CHI. J. INT’L L. 605 (2007). 
Langdell used cases as the most basic units of his jurisprudential theory, ${ }^{40}$ Islamic Langdellianism supplements the few, undefined, and largely incomplete legal edicts of the Qur'an with "cases” of its own; namely, the hadith, which are statements, actions, or utterances of the Prophet Muhammad in particular contexts, such as Muhammad informing the believers not to sell uncaught fish or the sperm of a stallion. ${ }^{41}$ The hadith and the Qur'an are the two primary sources of law, ${ }^{42}$ and, because the interpretive system does not admit of the possibility of $\mathrm{Mu}$ hammad's hadith violating the Qur'an, the more numerous and specific hadith act in effect as a superior source of law. ${ }^{43}$

The superiority of the hadith to the Qur' an is further demonstrated by the method by which they are to be verified for authenticity. Langdell asserted that the proper cases needed to be selected in order to develop the theory, but never specified the methodology to employ in the selection process. ${ }^{44}$ However, Islamic Langdellianism is much more careful in determining whether a given statement or action actually originated with Muhammad himself. The methodology does not involve considerations of equity, public interest, or even harmony with the Qur'an. Rather, authenticity is determined in the first instance on the basis of a chain of supposedly reliable narrators known as an isnad, often going back nearly two centuries, reporting a statement of Muhammad. ${ }^{45}$ For example, "And Malik, [who has heard] from Zaid son of Aslam [who has heard] from Atta son of Yasar, [who has heard] from Bassir son of

40. Grant Gilmore, The Ages of AMERICAN LAW 42 (1977).

41. See note 62 and accompanying text, infra.

42. M. Cherif Bassiouni \& Gamal M. Badr, The Shari'ah: Sources, Interpretation, and RuleMaking, 1 U.C.L.A. J. ISLAMIC \& NEAR E. L. 135, 139-40 (2002). The Shi'a expand the hadith to include the statements and utterances of particular descendants of Muhammad known as the Imams. LESSONS IN ISLAMIC JURISPRUDENCE, supra note 18, at 192. The role of the Imams in Shi'a jurisprudence and theology is described in more detail in Section II.A, infra.

43. An excellent example of this lies in the Prophetic hadith prescribing death by stoning to be the punishment for non-marital relations (zina) for non-virgin women, a punishment that remains law in some Islamic countries to this day. See, e.g., Vanessa Von Struensee, Stoning, Shari'a, and Human Rights Law in Nigeria, 11 WM. \& MARY J. WOMEN \& L. 405 (2005). This punishment, however, lies in flat contradiction to the Qur'an, which prescribes one hundred lashes for any man or woman engaged in sexual relations outside of marriage. QUR'AN 24:2. Islamic Langdellianism explains away this contradiction by suggesting that the hadith do not so much contradict the Qur'an's rule as provide a limited exception to it in the case of non-virgins. MUHAMMAD IBN IDRIS AL-SHAFI'I, AL-RISALA, ๆ 227 (1st ed. 1940).

44. See GILMORE, supra note 40, at 47 (indicating that according to Langdellian theory "the function of the legal scholar...is to winnow out from the chaff those very few cases which have ever been correctly decided and which, if we follow them, will lead us to the truth").

45. BADRAN ABU AL-AYNAYN BADRAN, UsUl AL-FIQH 74-75 (1965); see also Muhammad Ibn Idris al-Shafi'i, Kitab Ikhtilaf Malik wa Shafi'i, in 8 AL-UMm 513 (Abdul Muttalib ed., 2001). 
Sa'id, [who has heard] from al-A'raj, who reports that Abu Huraira heard [Muhammad] state...." 46

Langdell derived from his cases fundamental principles from which, through deductive logic, he derived clear, specific, and formal rules whose application was uncontroversial when applied to stipulated facts. Islamic Langdellianism, by contrast, uses a variety of quasi-logical techniques under the rubric of qiyas to expand the scope of its cases, the hadith, well beyond their original terms. ${ }^{47}$ Often, qiyas acts as a type of pure analogical reasoning, banning, for example, the consumption of all intoxicants on the basis of a Qur'anic date wine prohibition. ${ }^{48}$ At other times, however, qiyas employs a type of a fortiori reasoning more deductive in nature, forbidding, for example, the consumption of a large portion of an item if the consumption of a smaller portion was forbidden. ${ }^{49}$ Thus, Islamic Langdellianism is not a two step process, whereby a case or series of cases is transformed into a fundamental principle from which rules are then derived, but rather a one step process, whereby "cases" are expanded into broader "fundamental rules" using logic-driven principles and processes.

Moreover, whereas Langdell through the application of rigorous deductive logic could develop formal rules relatively noncontroversially, Islamic jurists employing a doctrine such as qiyas could differ on the proper application in order to reach a particular result. In such a case, there could be no single "legitimate" rule. ${ }^{50}$ Certainly much of Islamic jurisprudence in the classical era obsesses over the casuistic differences of interpretations between jurists over applications of qiyas, and jurists are careful not to dismiss competing applications as per se illegitimate. ${ }^{51}$ Nevertheless, to minimize the possibility of such divergence to the extent possible, Islamic Langdellianism employs another important tool known as ijma, or consensus. Under ijma, as employed by the Is-

46. Shafi'i, supra note 45 , at 515 .

47. Wael B. Hallaq, Legal Reasoning in Islamic Law and the Common Law: Logic and Method, 34 CLEV. ST. L. REV. 79, 82-95 (1985-1986).

48. Id. at 88-89 (citing this popular example).

49. See SHAFI'I, supra note 43, ๆ 1483.

50. Even the rule over precisely which intoxicants were prohibited through qiyas on the basis of the date wine prohibition led to considerable debate within the juristic community in the classical period. MATHEW LIPPMAN ET AL., ISLAMIC CRIMINAL LAW AND PROCEDURE 47-48 (1988).

51. For an excellent example of a casuistic dispute respecting the scope of a ban on certain forms of commercial uncertainty in the classical era and the manner in which a premier medieval jurist carefully describes the various positions of competing jurists without delegitimizing any of them, see 2 MUHAMMAD IBN AHMAD IBN RUSHD, BIDAYAT AL-MUJTAHID [THE DiSTINGUISHED JURIST'S PRIMER] 177-81 (1970). 
lamic Langdellians in the context of Islamic finance, if a juristic consensus develops with respect to a particular application of qiyas, then that application is canonized as correct, and any subsequent competing interpretation on the part of any jurist anywhere at any time is per se illegitimate. $^{52}$

These four sources, the Qur'an, the hadith, ijma, and qiyas, are the four principal bases of Sunni Islamic jurisprudence and lead to a highly formalist system in the Langdellian sense given the relative absence of anti-formalist tools through which rules might be developed. ${ }^{53}$ As a result, it is clear that in the derivation of rules, as a methodological matter, the functionalism that is necessary to achieve such broader societal aims as public interest or social justice is largely absent.

\section{B. Islamic Langdellianism in Application-Riba and Gharar}

To understand the extent to which Islamic law in its current manifestation in the world of Islamic finance is supremely unconcerned with functionalism, one need look no further than the two central prohibitions within Islamic finance today, the first concerning interest on loans and the second concerning certain forms of commercial uncertainty.

As concerns the taking of interest, the ban developed from the Qur'anic prohibition of riba. As with much of the Qur'an, however, the verses concerning riba are largely undeveloped. The verses condemn riba in strident terms, ${ }^{54}$ indicate it is entirely different from ordinary sale (bai'), ${ }^{55}$ suggest it involves illicit and enormous profit, ${ }^{56}$ juxtapose it unfavorably as against acts of charity, ${ }^{57}$ and compare it in principle to

52. BADRAN, supra note 45, at 216 ("[W]hen an ijma is built on [an application of] qiyas, it renders that [application] something over which none may differ.”). Certainly this understanding of ijma has led proponents of Islamic finance to dismiss alternative interpretations of Islamic doctrine concerning the application of interest to be fundamentally illegitimate.

53. Other anti-formalist doctrines, of far lesser significance and far greater controversy, are available in the Sunni tradition. Most importantly, there are the twin doctrines of istihsan and istislah, which might be loosely rendered into English as equitable consideration and public interest, respectively. Not all jurists accept the legitimacy of these doctrines, however, and in any event in their modern manifestations both have withered substantially and are of only marginal value in the broader context of the Islamic Langdellian system. See MuHAMmad ABU ZAHRA, USUL AL-FIQH [PRINCIPLES OF JURISPRUDENCE] 251-254 (1969).

54. QUR'AN 4:161 (promising a "painful punishment" for those who "devour" riba and those who "devour" the property of others falsely).

55. QUR'AN 2:275.

56. QUR'AN 3:130 (“Oh ye who believe, do not devour riba, making it double and redouble....”).

57. See QUR'AN 30:39 (“And whatever you lay out as riba, so that it may increase in the property of men, it shall not increase with Allah; and whatever you give in charity, desiring Al- 
a form of theft. ${ }^{58}$ However, nowhere are the parameters of the activities that constitute riba defined.

The central hadith upon which Islamic finance relies to justify the interest prohibition characterizes as riba certain trades in gold, silver, grain, salt, barley, and dates unless hand to hand and without delay. ${ }^{59}$ Islamic finance experts claim that these trade prohibitions encompass money through qiyas and that this application of qiyas has been canonized through ijma. ${ }^{60}$ They dismiss competing interpretations as "defeatist" or "apologetic.",61

The ban on particular forms of commercial uncertainty, known as gharar, is based largely on hadith that ban, for example, the sale of fish in the sea or the sperm of a stallion. ${ }^{62}$ Many of these hadith have like-

lah's pleasure, you shall get manifold.”).

58. QUR'AN 4:161.

59. 3 ABDUl-RAZZAQ Al-SANHURI, MASAdir AL-HAQQ FI AL-FIQH AL-ISLAMI, DiRASA MUQARINA MA' AL-FIQH AL-GHARBI [THE SOURCES OF RIGHTS IN ISLAMIC JURISPRUDENCE: A COMPARATIVE STUDY WITH WESTERN JURISPRUDENCE] 177 (1967). A similar version appears in the Risala as well. SHAFI'I, supra note 43, ๆ 1518.

60. Jurists in the classical era were quite clearly not focused on loans given this hadith, but rather on trades of particular items for others. See, e.g., 3 SANHURI, supra note 59, at 178-94. The heightened emphasis on a loan ban derived from the trade prohibition is entirely modern, which is all the more puzzling given that contemporary currency is not based on the value of any precious metal or other item listed in the hadith. Moreover, the types of functional demands discussed in this Article that modern Muslims tend to make concerning Islamic finance and economics are largely absent from the contemplations of the classicists, allowing many classical jurists to embrace openly the most transparent of artifices to circumvent the interest prohibition. The Hanafis and Shafi'i schools, for example, permit the sale of a particular item and its immediate buyback by the seller for a higher amount as way to mimic an interest based transaction. See, e.g., NiCHOLAS DYLAN RAY, ARAB ISLAMIC BANKING AND THE RENEWAL OF ISLAMIC LAW 56-57 (1995); ABDULLAH SAEED, ISLAMIC BANKING AND INTEREST 38-39 (2d ed. 1999). However, to expound at length on precisely the manner in which the jurists of the classical era approached shari'a so as to countenance such artifices would be beyond the scope of this Article. It suffices to say that the absolute refusal of Islamic finance to adopt the simplest artifices of the classical era, including the sale and immediate buyback, notwithstanding their clear classical pedigree, and opt instead for more obfuscatory and potentially deceptive forms of artifice to mask to the broader community the similarity of the transaction to conventional forms of finance provides yet more evidence that Muslims in the modern era expect more functional relevance from contemporary Islamic financial practices.

61. See Khurshid Ahmad, Foreword to Muhammad NeJATUllah SidDiQui, Banking WiTHOUT INTEREST 7 (rev. ed. Islamic Found. 1988) (1973) (describing a similar position as "defeatist”); Mohammad Uzair, The Impact of Interest Free Banking, 3 J. IsLAMIC BANKING \& FIN. 39, 40 (1984) (describing the exemption of interest from the riba prohibition to be "apologetic"); see also COUNCIL OF ISLAMIC IDEOLOGY, CONSOLIDATED RECOMMENDATIONS ON THE ISLAMIC ECONOMIC SYSTEM app. 7 (1983) (indicating the presence of "complete unanimity among all schools of thought in Islam that the term riba stands for interest in all its types and forms").

62. See Frank E. Vogel \& SAMUel L. Hayes, III, ISLAmiC LAW AND FinANCE: Religion, RISK AND RETURN 87-88 (1998); IBN RUSHD, supra note 51, at 169-70 (1970). 
wise been expanded through qiyas and purportedly sanctified through ijma to encompass astonishing levels of contemporary commercial risk, so that contracts cannot contain uncertainty over fundamental matters, such as, for example, a contract for the sale of an item not yet in existence. ${ }^{63} \mathrm{~A}$ fortiori, it has been argued, insurance contracts are per se invalid, given the uncertainty concerning not only the timing of the payout, but indeed its very existence. ${ }^{64}$ Functionally, therefore, as currently construed the rule is entirely perverse; it requires individuals to enhance the levels of uncertainty and risk in their lives, purportedly on the basis of a verse whose purpose is to prohibit them from doing that.

Thus, the flaws in the rigid Langdellian system are immediate and obvious. These flaws prevent jurists from developing doctrine that achieves articulated broader societal interests.

\section{SHI'ISM's ORGANIZATIONAL AND RELIGIOUS AUTHORITY}

Sadr's functional challenge in Iqtisaduna to the principles of modern Islamic jurisprudence is very much grounded in certain particularities of Usuli Shi'i religious thought concerning religious authority. A proper understanding of Sadr's ideas, therefore, requires a certain familiarity with these background fundamentals and with Sadr's life and works generally within the Usuli framework. ${ }^{65}$

\section{A. Shi'ism and the Imamate}

According to Shi'i legend, the Shi'i-Sunni schism originated in the question of successorship to the Prophet Muhammad. The Sunnis claimed that Muhammad specified no successor, and, therefore, Muhammad's proper successor was to be designated by the community. The Shi'a, shortened from Shi'at Ali, or the partisans of Ali, claimed

63. See 3 SANHURI, supra note 59, at 33-34.

64. VOGEL \& HAYES, supra note 62, at 150.

65. Because entirely irrelevant for the purposes of this Article, I make no attempt to evaluate the historicity of the legends described in this Part and instead merely engage them on their own terms. To understand Sadr's ideas, the actual history of Shi'ism is considerably less important than the legends that have developed to explain the theology that Sadr and his fellow jurists propound. My selection of sources reflects this bias, relying on traditional accounts such as those of Moojan Momen and Allamah Tabataba'i to the exclusion of more rigorous historical versions. See Moojan Momen, A History OF SHI'I Islam, at xiv (1985) (“Critical scholarship has produced some interesting research on Shi'i Islam, particularly concerning its early history and this has tended to throw considerable doubt on the traditional Shi'i accounts. However, this research...has had no impact at all on Shi'i Islam itself, neither on the Shi'i religious leaders nor on the Shi'i masses.”). 
that Muhammad, carrying out Divine Command, had clearly and unequivocally named his son-in-law Ali as his heir. The basis for the Shi' $i$ claim was a hadith by Muhammad, disputed or interpreted differently by Sunnis, on a day known as Ghadir Khumm, in which he declared in one of his final sermons that whoever had accepted him as guardian of the Muslim community must now likewise accept Ali. ${ }^{66}$ The importance of the Ghadir Khumm hadith cannot be underestimated; to this day, the anniversary of Muhammad's sermon at Ghadir Khumm is widely celebrated in nations with large Shi'i populations. ${ }^{67}$

If viewed entirely as a political event, this celebration seems odd because Ali did not gain political power upon Muhammad's death; rather, the Sunni claim that the community should decide prevailed and the first caliph, Abu Bakr, was granted political authority over the community. ${ }^{68}$ Importantly, however, the Shi'i claim transcends the political in that the Shi'a consider Ali to be not only Muhammad's legitimate political heir, but also a religious heir and the true source of knowledge (marja' al-ilm) by virtue of his infallibility and his intimate connection to the Divine. ${ }^{69}$ Ali's title among the Shi'a, therefore, was not simply caliph but Imam, ${ }^{70}$ selected by God and deemed uniquely capable of understanding not only what might be termed the "plain meaning" of the Qur'an, but its “hidden meaning” (ta'wil) as well. ${ }^{71}$

The Imam is not a Prophet under Shi'i doctrine, in that he is not sent a Divine Book to supplant or supplement the Qur'an, but his religious authority, given his proximity to God, is clearly unique within the community. ${ }^{72}$ Nowhere within Sunni legend is there any suggestion that any religious or political authority has some sort of comparable ability to understand the Qur' an entirely. ${ }^{73}$

66. TABATABA'I, supra note 21, at 40.

67. The author has himself witnessed large congregations in Iraq gathering throughout the anniversary of the Ghadir Khumm sermon to celebrate this event despite the fact that the day is not recognized as a national holiday.

68. ТАВАТАВA'I, supra note 21 , at $41,44$.

69. Id. at 41-42.

70. It is important to note that the term Imam is also used by Sunnis, and sometimes by Shi'a, to refer to a religious authority, particularly one who might be leading prayers. However, the notion of Imam as an infallible authority who leads the community is uniquely Shi'i. See LESSONS IN ISLAMIC JURISPRUDENCE, supra note 18, at 180-82.

71. TABATABA'I, supra note 21, at 98-99; see also Seyyed Hossein Nasr, Preface to id. at 10 (indicating that " $[t]$ he distinctive institution of Shi'ism is the Imamate and the question of the Imamate is inseparable from...the esoteric function of interpreting the inner mysteries of the Holy Quran and the Shari'ah").

72. See TABATABA'I, supra note 21 , at $185-86$.

73. Shafi'i repeatedly insisted that the decisions of the Companions of Muhammad were not 
Upon Ali's death, a series of his lineal descendants succeeded him, with the line ending ultimately in the twelfth Imam, the Mahdi. ${ }^{74}$ The Mahdi disappeared into hiding in what is known as the Greater Occultation (ghaybat al-kubra), but remains alive and will reappear in the future. $^{75}$ Therefore, the Mahdi is the sole authority on earth capable of fully comprehending the Qur'an. However, because he has been in hiding for more than a millennium, Shi'i Islam required some form of subsidiary religious authority, if not to replace him, then to act as his deputy in his absence. As the next section will show, it was the scholars of the law, currently known as the marja'iyya, who assumed this position in the modern era in the current manifestation of Shi'ism known as Usuli Shi'ism.

\section{B. Shi'i Religious Authority in the Modern Era}

\section{Principles of Usuli Shi'ism}

Usulism, which came to dominate Shi'ism by the end of the eighteenth century, ${ }^{76}$ permits the exercise of interpretive effort on the part of jurists, known as ijtihad, ${ }^{77}$ on the basis of four sources of law remarkably similar to those of Sunni Islam; namely, the Qur'an, the hadith, which encompass not only the actions and utterances of Muhammad but also those of the Imams, ijma and aql, or a form of logical reasoning similar to qiyas albeit without the analogical implications. ${ }^{78}$ To add fur-

sources of the shari'a in contradistinction to the hadith of Muhammad. See JOSEPH SCHACHT, THE ORIGins OF MuHAMMAdAN JuRISPRUdENCE 16-17 (1950). Among the Companions were the most highly respected of Sunni Islam's caliphs, the first four, also known as the "Rightly Guided.” DOMinique SOURDEl \& JANine SOURDEL-ThOMINE, A GlosSARY OF ISLAM 143 (Caroline Higgitt trans., Edinburgh Univ. Press 2007) (2002). Logically implicit in Shafi'i’s contention, therefore, is not only the idea that none of the caliphs carried any secret ability to understand the Qur'an, but also that they were capable of error.

74. The term "twelver" Shi' ism thus owes its origins to the number of Imams that Twelver Shi' is believe succeeded Muhammad. SOURDEL \& SOURDEL-THOMINE, supra note 73, at 175.

75. TABATABA'I, supra note 21, at 190-211 (providing an account of the twelve Imams). The Greater Occultation derives its name in juxtaposition to the Lesser Occultation that preceded it, which was a period of time during which the Mahdi was supposedly in hiding but nonetheless in contact with select deputies. Id. at 210-11.

76. Usuli Shi'ism is usually contrasted with the other prominent form of Twelver Shi'ism that existed in the early eighteenth century, Akhbarism. Akhbaris generally believed that the exercise of ijtihad was forbidden to all but the Imam because humans are capable of error. MALLAT, supra note 5 , at 28-30.

77. For a more detailed treatment of ijtihad, see Section III.C.2, infra.

78. Hossein ModarRessi TABATABA'I, AN InTROdUCtion to SHi's LAW 3-4 (1984). A paradigmatic example of $a q l$ is the "rule of correlation" (qaidat al-mulazama), pursuant to which, 
ther similarity to the shari'a as developed by Shi'is and Sunnis, the hadith of the Imams often suspiciously track the conclusions of the Sunni jurists employing qiyas. For example, two schools of thought within Sunni Islam define the items that cannot be traded under the terms of the riba hadith as those measurable by weight and those measurable by volume. ${ }^{79}$ The Shi'a reach this precise conclusion more directly; they report a hadith of the third Imam to the effect that items measured by weight and volume are subject to the prohibitions of riba. ${ }^{80}$

As a result, in practical terms, the differences between Sunni jurists and Shi'i jurists in their contemporary derivation of shari'a are largely casuistic; ${ }^{81}$ both are exercises in Langdellian formalism. There has been increasing willingness, given this, to recognize traditional Shi'ism as simply another school of thought (madhab), akin to the four traditional schools of Sunni jurisprudence. ${ }^{82}$

However, while the differences between the sects may be exceedingly slight juridicially, the theological principles relating to the existence of an Imam do create considerable distance between them. The Shi'i jurist engaging in the interpretation of text is doing so in the hidden presence of an Imam who is himself almost an embodiment of the Law, and the jurist therefore acts in some sense as a caretaker for the Imam. The result is a clear bifurcation of authority within the Shi'i community between those capable of deriving the shari'a, known as mujtahids, or practitioners of ijtihad, who act as trustees for the Hidden Imam, and lay people, who are known as muqallids, or imitators. ${ }^{83}$ Given the inherent authority of the Usuli Shi'i jurist as the Imam's deputy, a certain unique level of hierarchy and organizational structure fol-

among other things, the prerequisites of an obligatory act are deemed obligatory and the direct opposite of an obligatory act is deemed prohibited.

79. 3 SANHURI, supra note 59 , at 198.

80. 5 MUHAMMAD IBN YA'QUB AL-KULAYNI, Usul AL-KAFI 146 (1985) ("Riba does not lie in what cannot be measured by weight or volume.”); see also 7 MUHAMMAD IBN AL-HASAN ALTUSI, TAHDHIB AL-AHKAM 118 (1981) (discussing Hadith of Third Imam that "everything measurable by weight or volume may not be traded two for one if they are of the same genus").

81. MOMEN, supra note 65, at 184.

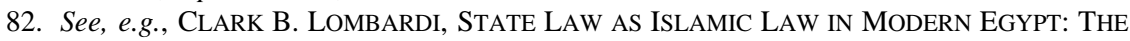
INCORPORATION OF THE SHARI'A INTO EGYPTIAN CONSTITUTIONAL LAW 82 n.2 (2006) (citing a 1959 ruling by the rector of Al-Azhar, one of the premier centers of learning within Sunni Islam, suggesting that Shi'i legal opinions were as valid as legal opinions of the four Sunni schools).

83. MALLAT, supra note 5, at 31. For ease of understanding, I refer to these "imitators" as "followers" or "laity." It should also be noted that the bifurcation in Sunni Islam between muqallids and mujtahids is an immensely different one, in that both are involved in a form of interpretation, whereas within Shi' ism, the muqallid is very much a lay follower not involved in any aspect of interpretation. See, e.g., JACKSON, supra note 22, at 94-96 (discussing the role of muqallids in classical Sunni Islam). 
lowed. Specifically, under Usuli principles, each lay person was required to select a single, living mujtahid to "imitate." 84 The lay person was free to make his selection among the available mujtahids based on who he considered the most knowledgeable. ${ }^{85}$ He was then required to follow the rulings of the one mujtahid he selected without question. ${ }^{86}$

Professor Mallat wisely explains the requirement of the living mujtahid as being related to the requirement of a continually creative jurisprudence, ${ }^{87}$ but he may be discounting the political, social, and economic dimensions of the issue. Mujtahids are involved in a fair amount of competition with one another for followers, and the followers are required under Shi'i rules to pay one tenth of their earnings less necessary expenses to the mujtahid as the Imam's trustee. ${ }^{88}$ Permitting such prestige and power to go to the dead in the place of the living hardly seems expedient from the point of view of the living mujtahids.

Given the significant levels of control exercised by mujtahids over the community, Usuli Shi'i Islam needed to develop some sort of organizational structure and system through which the process of "mujtahidization" could take place, or the system would promptly disintegrate as the numbers of self-proclaimed mujtahids multiplied and the followers selected whoever they wished among them or, alternatively, proclaimed themselves to be mujtahids. The system also needed to operate within a second constraint; it could not be enforced politically because the hierarchy operated entirely independently of the state. ${ }^{89}$ What eventually developed as a result of the need for hierarchy that lay beyond the realm of the political were organized Shi'i centers of learning, primary among

\footnotetext{
84. MuHAmmad BAQIR AL SADR, Al FATAWA AL WADiHa 21 (1977).

85. Id.

86. Id.

87. MALLAT, supra note 5, at 31 .

88. The rules regarding this obligatory payment, known as khums, further highlight the premier role of the Shi'i jurists within the community. A verse of the Qur'an orders the believers to pay from whatever "spoils" they acquire one fifth to Allah, Muhammad, Muhammad's relatives and the poor and wayfarers. QUR'AN 8:41. Shi'i jurisprudence suggests somewhat implausibly that "spoils" refers to general earnings beyond necessary expenses and requires that $20 \%$ of these "spoils" be paid by followers in accordance with a set of rules. See e.g., SAYYID ALI HUSAINI SISTANI, MINHAJ AL-SALIHEEN, Introduction to I 1212, available at http://www.sistani.org/local.php?modules=nav\&nid=2\&bid=22\&pid=1926 (describing income from trade, industry, agriculture and possessions, along with other matters, as subject to the khums requirement). Half of the khums belongs to the Hidden Imam and half to the needy living descendants of Muhammad. Id. I 1259; MALlAT, supra note 5, at 44-45. During the Greater Occultation, the first half, known as the sahm al-Imam, is to be given directly by the follower to his mujtahid, who will act as the Imam's deputy and spend it on the Imam's behalf. SISTANI, supra at 1265.
}

89. MALLAT, supra note 5 , at 44-45. 
them Najaf, the city in Iraq where the body of Shi'ism's founder, Ali, lays buried. ${ }^{90}$

\section{The Role of the Mujtahids ${ }^{91}$}

The religious schools of Najaf were remarkable for their ability to meld a formal organizational structure onto an informal educational process within which hierarchy was never firmly established. On the one hand, the schools produced the mujtahids whose rulings were authoritative on matters concerning the shari'a within the Shi'i community. ${ }^{92}$ On the other hand, the marja'iyya confers no formal degree, and the attainment of the title of mujtahid is gradual, with the final stage being one of a final and absolute mujtahid, the marja al-taqlid ("marja"”), or source of imitation. ${ }^{93}$ Because there is no formal degree, there is no announcement that any particular scholar has become a marja', though the Shi'i community is always aware of who the marjas are at any given time. ${ }^{94}$

As a student rose, both in scholarly reputation and, upon achieving the level of marja al-taqlid, in the number of his followers that selected him as their mujtahid (and consequently paid him one tenth of their earnings), his rank rose as well. ${ }^{95}$ Two factors, therefore, controlled the rise of the putative jurist through this lengthy process that would exceed

90. See id. at 38; Bernard K. Freamon, Martyrdom, Suicide, and the Islamic Law of War: A Short Legal History, 27 FORDHAM INT’L L.J. 299, 334-35 (2003).

91. For ease of reference to the aspiring scholar, I cite most often in this section to the laudable work of Chibli Mallat in describing the functioning of the marja'iyya. I should note, however, that all of this has been confirmed by me during a two-year stay in Iraq from 2003 to 2005 during which I held extensive conversations with various aspiring scholars in the Najaf seminaries.

92. Virtually all of the influential Shi'i scholars of the latter half of the twentieth century studied in Najaf, including Sadr, Ayatollah Khomeini, who led the 1979 Islamic Revolution in Iran, and Grand Ayatollah Sistani, whose current influence in Iraqi political and civil affairs is considerable according to virtually all political and religious authorities in Iraq with whom I spoke. See also MALLAT, supra note 5, at 59, 65 (concerning Sadr and Khomeini in Najaf); Corine Hegland, In Iraq, Sistani Is the Chess Master, NAT’L J., Apr. 17, 2004, at 1200-01 (concerning Sistani); note 214, infra.

93. See MALLAT, supra note 5, at 42-44 (describing the process of "graduating" from Najaf seminaries); see also SADR, supra note 84, at 29 (describing the highest level of attainment).

94. For example, there are currently four marjas', commonly referred to as Grand Ayatollahs, in Najaf: Ali Sistani, Bashir Najafi, Ishaq Fayyad, and Muhammad Sa'eed Hakim. Virtually any pious Shi'i would be able to recite this list of four names, and certainly I have never heard any dispute about this. This is remarkable in light of the fact that there is no official process of appointment and that the sole manner in which the matter is determined is by consensus of the juristic community.

95. MALLAT, supra note 5, at 56. 
two decades: his reputation within the marja'iyya and within the broader scholarly community and the willingness of followers to select him as their marja'. ${ }^{96}$ The laity therefore serves an important role in the process, essentially confirming and raising the stature of particular marjas selected by the marja'iyya.

Importantly, the mujtahids work largely in parallel with one another rather than in concert; no formal meetings are held by which decisions are agreed to, but rather each mujtahid develops his own rules and trains rising jurists in his own seminary. ${ }^{97}$ Inevitably, however, some form of coherence develops due to their centralization in Najaf and the dissemination of their ideas within the rarefied juristic community. Jurists are in necessary competition for followers, and a radical departure from the rulings of other jurists might not only impact the jurist's reputation among his peers, but also lead to a substantial decrease in the number of devoted followers. As a result, the differences among jurists as to their understandings of the shari'a are relatively slight.

\section{The Rise of Sadr}

Born in 1935, Sadr rose rapidly through the scholarly ranks of Najaf's religious schools during a period of considerable tumult in Iraq, and he was quickly considered a successor to a Grand Ayatollah before he reached the age of $40,{ }^{98}$ no small feat given the decades of learning normally required to attain the level of mujtahid. The nation was at the time convulsed by a series of coups beginning in 1958, as a result of which political control of the country had shifted between and among a variety of secular parties, among them pan-Arabists (including the Ba' ath party of Saddam Hussein), communists, and Iraqi nationalists. ${ }^{99}$

At least during the early part of this era, the marja'iyya was largely irrelevant to the political machinations and turned largely in on itself. Its mujtahids were devoting the bulk of their scholarly effort to developing what is known as a risala, or epistle, comprising the details of the shari'a, which often was little more than a recitation of the work of previous scholars and offered little opportunity for innovation. ${ }^{100}$ The focus

96. See id. at 39-41, 44-45.

97. Id. at 39 .

98. See Mottahedeh, Introduction to LESSONS IN ISLAMIC JURISPRUDENCE, supra note 18, at 28-30.

99. Phebe Marr, The Modern History of Iraq 81-176 (2d ed. 2004); Aziz, supra note 31, at 208-11.

100. MALlAT, supra note 5, at 47-48. The risala remains the central work of the marja', and it is hard to enter the home of any devout Shi'i in Iraq without finding the risala of his mujtahid, 
of the risala was, and continues to be, on details concerning the rules of ritual. $^{101}$

The most prominent marja' during Sadr's youth, Muhsin al-Hakim, deplored political involvement and seemed to find some comfort in the relative isolation of the marja'iyya from the machinations of the profane world. ${ }^{102}$ Hakim sought, instead, protection for the Najaf scholars from political interference in exchange for relative political apathy. ${ }^{103}$ His involvement in political affairs was limited to issuing some number of juristic opinions, or fatwas, of limited scope, such as his prohibition against joining the Communist party because of its atheism and his refusal to meet with Iraq's president unless he repealed a civil liberties law that Hakim considered unIslamic. ${ }^{104}$ As a result of this disengagement, the Shi'i laity had grown increasingly disaffected with the marja'iyya and increasingly enamored of communism. ${ }^{105}$ Sadr's revolutionary mission was largely to reverse this trend and to make the marja'iyya of central relevance in the time of turmoil. His work was written in a largely accessible fashion, addressing, in addition to economics, modern Shi'i notions of philosophy and logic in contrast to those of Marxism. ${ }^{106}$ He began to work towards reforming the seminaries of Najaf as well by attempting to make them more structured, to use textbooks that were more accessible to beginning students, and to expand their curriculum beyond the arcane rules of the shari'a and the means by which the rules are derived. ${ }^{107}$

Sadr also sought to become relevant politically. These aspirations were held in check as an initial matter while Hakim was the most senior

which can be in excess of 10 volumes.

101. See generally SISTANI, supra note 88 (providing part of the risala of Grand Ayatollah Sistani).

102. Mottahedeh, Introduction to LESSONS IN ISLAMIC JURISPRUDENCE, supra note 18, at 28-29.

103. Id. There is some debate as to how politically involved Hakim was, with some pointing to actions taken by some of his closest confidants and associates concerning legal developments in Iraq after the 1958 coup. See, e.g., MALLAT, supra note 5, at 15-16 (concerning opposition to legal reforms in the family law area); JOYCE N. WILEY, THE ISLAMIC MOVEMENT OF IRAQI SHI'AS 46-47 (1992) (concerning deportation of Iraqi Shi'a and harassment of Shi'i seminarians). 104. Aziz, supra note 31, at 209.

105. MALlAT, supra note 5, at 36-37; Mottahedeh, Introduction to LESSONS IN ISLAMIC JURISPRUDENCE, supra note 18, at 28.

106. See generally MUHAMMAD BAQIR AL-SADR, FALSAFATUNA (1969) (English translation available at MUHAMMAD BAQUIR AS-SADR, OUR PHILOSOPHY (Shams C. Inati trans., The Muhammadi Trust 1987) (concerning philosophy); MUHAMMAD BAQIR AL-SADR, AL-UsUS ALMANTAQIYYA LIL ISTIQRA' (4th ed. 1977) (concerning logic).

107. Mottahedeh, Introduction to LESSONS IN ISLAMIC JURISPRUDENCE, supra note 18, at 29; Aziz, supra note 31, at 210-11. 
cleric in Najaf largely because Hakim demanded in 1961 that Sadr distance himself from an Islamist political party that Sadr had himself founded three years earlier. ${ }^{108}$ However, after Hakim's death and as Ba'ath control of Iraq began to consolidate, Sadr's interest in politics and juristic political involvement increased. He wrote a series of works that explicitly called for a political revolution in Iraq and a form of juristic rule that the Ayatollah Khomeini would later use as a template for Islamic government in Iran. ${ }^{109}$

Sadr's political activism throughout the 1970s led to increasing difficulties with the Ba'ath authorities in Baghdad, and his efforts to transform the marja'iyya likewise met with increasing resistance. ${ }^{110} \mathrm{He}$ sought to address these two problems through solidifying his reputation within the marja'iyya because he believed that the Baghdad government would never harm a mujtahid of sufficiently high standing and that reform of the institution was impossible unless he was of higher rank. ${ }^{111}$

Thus, as his political difficulties were reaching a climax in $1977,{ }^{112}$ Sadr finally turned to the preparation of the first volume of something that he called Al-Fatawa al-Wadiha (The Clear Rulings), which resembles a risala but by Sadr's own admission omits the lengthy and cumbersome details that demonstrate the basis of the rulings in question. ${ }^{113}$ Professor Mallat notes that Sadr's failure ever to produce such a risala has been attributed to his premature death, ${ }^{114}$ but the explanation seems hardly convincing in the case of a jurist who had already written so extensively on so many other subjects. It seems Sadr had never thought very much of the risala; even the introduction to the Fatawa makes this amply, if implicitly, clear. ${ }^{115}$ A more likely explanation for Sadr's delay is that Sadr felt that that the risala was largely irrelevant to the lay community, and thus devoted his efforts in other directions. Only when it became clear that his revolution and his life depended in part on the

108. Mottahedeh, Introduction to LESSONS IN ISLAMIC JURISPRUDENCE, supra note 18, at 29-30; Aziz, supra note 31, at 207-11.

109. See MAllat, supra note 5, at 69-78 (describing Sadr's influence on the Iranian Constitution and on Khomeini's work, Wilayat al-Faqih).

110. Mottahedeh, Introduction to LESSONS IN ISLAMIC JURISPRUDENCE, supra note 18, at 31; Aziz, supra note 31, at 213-14.

111. Aziz, supra note 31, at 213.

112. Id. at 213-15.

113. See generally SADR, supra note 84 .

114. MALLAT, supra note 5, at 13.

115. SADR, supra note 84, at 11-14 (criticizing the risala for its lack of organization and its arcane terminology and suggesting that as a result it does not communicate effectively to the lay follower). 
support of the marja'iyya did he finally turn to the preparation of a risala. In the end, however, the effort was in vain. Difficulties with the Ba'ath regime continued, particularly after Sadr's support of Khomeini's revolutionary efforts in Iran. ${ }^{116}$ In April of 1980, Saddam Hussein arrested Sadr along with his sister and executed them almost immediately. ${ }^{117}$

\section{ThE Discovery OF IsLAMIC ECONOMICS}

Sadr's crowning achievement, Iqtisaduna, was written before Hakim's death in 1970 and thus before Sadr had an opportunity to develop his political thought because Hakim had expressly forbidden the younger Sadr's extensive engagement in politics. As a result, Sadr seems eager in Iqtisaduna not to invite debate about political order. He thus only indicates that political authority will be exercised by a Holder of Command (Wali al-Amr), which is a popular Qur'anic term, ${ }^{118}$ without providing the level of specificity that he later developed and that later inspired Ayatollah Khomeini in the development of his seminal work Wilayat al-Faqih, or Guardianship of the Jurist. ${ }^{119}$ This does not derogate from the revolutionary nature of Iqtisaduna. As will be demonstrated, Iqtisaduna is a three part work with the first two parts dedicated to a dissection of the principles of Marxism and capitalism, respectively, and the third focused on what Sadr views as an entirely separate system, the Islamic economic system. ${ }^{120}$ The first two sections seem recycled and, with respect to the section on Marxism, respond in some detail to long discredited arguments concerning, for example, dialectics and historical materialism. ${ }^{121}$ The third part of the work, concerning Islamic economics, is by far the most interesting.

A complete summary of Iqtisaduna, or even its third section, is well beyond the scope of this Article. ${ }^{122}$ I therefore present only a portion of

116. Aziz, supra note 31 , at 214-17.

117. Mottahedeh, Introduction to LESSONS IN ISLAMIC JURISPRUDENCE, supra note 18, at 31.

118. QUR'AN 4:59 (“O you who believe, obey God and his Apostle and the Holder of Command among you....”).

119. See Section II.B.3, supra (discussing Sadr's influence over the form of government Iran was to adopt).

120. See generally IQTISADUNA, supra note 7.

121. See, e.g., id. at 32-43 (responding at length to Marxist theories that at this time are no longer seriously engaged).

122. It should also be noted that, despite the general brilliance of its author, Iqtisaduna suffers from such appalling organization that any competent summary would require extensive consideration of how to present all of the ideas in some sort of coherent fashion. Professor Mallat has done an admirable job of something close to this in his work, The Renewal of Islamic Law, but 
Sadr's ideas in a manner designed to expose better the extent of Sadr's radical approach towards a new form of social, cultural, and economic association in Islamic societies and the functional jurisprudence he uses to achieve this. The first subsection of this Part demonstrates how Iqtisaduna is functional in its very conception. The second outlines the neutral and objective role that shari'a was to play in the system, thereby distinguishing Sadr's ideas from the Critical Legal Theory movement in the United States to which Professor Jackson has called attention. The third section reveals the extent to which Sadr seeks to reformulate shari'a along deeply functional lines and accept at some level a broad role for subjective ideological and political choice in the derivation of shari'a. Finally, the fourth section exposes Sadr's theory in application. It shows how Sadr's jurisprudence developed functional ideas on mutuality in economic transactions that Sadr ascribed to the shari'a and that are certainly central to contemporary understandings of Islamic social and economic order. This section uses one example, Sadr's proposed prohibition on hired labor, to provide logical coherence (if not practicability) to this principle where Islamic economics and finance has heretofore failed to articulate sensible ideals and objectives.

\section{A. Conceptions of Economic Order}

\section{Delineation of Objectives}

Sadr indicates that Islamic economics is intended to serve three objectives: to ensure multiple ownership forms of property, to put in place limited economic freedom for commercial actors, and to achieve social justice in commercial affairs. ${ }^{123}$ By the mere process of identifying objectives, Sadr has already revealed a level of functionalism quite surprising for those familiar with the work of comparable Shi'i jurists. A risala, for example, offers no such "objectives"; in its place are technical, specific, and thoroughly derived rules, often along with the bases for these rules as derived using the standard Langdellian means, but cer-

even he is forced to omit significant portions, and some of the disorganization of the work is apparent from his descriptions. See MALLAT, supra note 5, at 113-41.

123. IQTISADUNA, supra note 7 , at 257. Sadr's concern with social justice throughout Iqtisaduna is remarkable and has not gone unnoticed among commentators. Hamid Algar, for example, describes Sadr as having produced "[t]he most substantial treatment of the subject of social justice in Islam.” Hamid Algar, Introduction to SAYYID QUTB, SOCIAL JUSTICE IN ISLAM 12 (John B. Hardie \& Hamid Algar trans., rev. ed., Islamic Publ’ns Int’l 2000). 
tainly no notion of a comprehensive system meant to achieve certain goals. $^{124}$

Moreover, in discussing his objectives, Sadr's revolutionary aims become clear. He is careful to avoid any suggestion that his economic system is some sort of "blend" of Marxism and capitalism. ${ }^{125} \mathrm{He}$ dismisses the notion that Islam mixes two foreign systems. Instead, he insists on recognition of the Islamic system in its own right as "a genuine and original doctrine built on specific ideological bases, lying within a framework of specific understandings and values (qayyim) that are inconsistent with the principles and bases and values and understandings

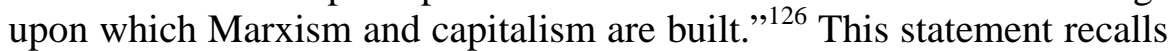
almost precisely Unger's assault on the objectivist notion that legal structure is logically derived from particular forms of human association, which, Unger claims, manifest themselves in "the conceit that we must choose between market and command economies or at most combine into a 'mixed economy' these two exhaustive and well-defined institutional options." 127 Sadr, like Unger, openly challenges these reductive assumptions and demands considerations of alternative structures clearly based on his own political and ethical norms.

\section{Doctrinal Theory of Economics}

While Sadr's objectives-driven approach to economics was certainly radical from the outset, it is his methodology that constitutes a clearer assault on traditionalist notions of Langdellian formalism in the Islamic context. Sadr begins his description of his methodological approach with the suggestion that Islamic economics is a doctrine (madhab) designed to serve the interests of human society within an overarching normative and religious framework that is specifically Islamic in character, central to which is a notion of social justice. ${ }^{128}$ The term madhab, commonly used to describe the schools of thought within the Langdellian interpretive modalities, is very significant. Economics, to Sadr, is not a scientific method of explaining the realities of particular forms of human association or deriving the rules of human association through some form of quasi-scientific logic-driven reasoning, but is rather a

124. See, e.g., SISTANI, supra note 88.

125. IQTISADUNA, supra note 7, at 256-57.

126. Id. at 259 .

127. Unger, supra note 13, at 568.

128. IQTISADUNA, supra note 7, at 264, 278-79 (concerning the central role of social justice and the position of economics within larger Islamic framework). 
means of designing a set of rules to achieve particular objectives. This is the very essence of functionalism. ${ }^{129}$

Thus, for example, Sadr dismisses the Marxist notion that historical and scientific forces of materialism will inevitably give rise to demands for equality that will ultimately require recognition. ${ }^{130}$ Sadr argues that the ambition for economic and social equality and social justice is ideological and normative and not merely a product of history. It was established, he argues, by Muhammad in seventh century Arabia through hadith indicating that Arabs and non-Arabs alike will be judged by piety and not ethnicity, that all humans are children of Adam and that humans are as equal as "teeth on a comb." "131 Sadr, like Unger, is highly critical of "necessitarian theories of historical change-the belief that the content and sequence of social systems reflect inescapable economic or psychological imperatives." 132 By debunking this theory, Sadr, like Unger, seeks the establishment of a new social system based on different normative understandings of human association. ${ }^{133}$ Moreover, and importantly, Sadr's assault on traditionalist notions of logic-driven jurisprudence is distinctly Islamic in character and calls upon stories of Muhammad himself in an effort at legitimization. As a deeply committed jurist, Sadr does not seek to discard Islamic doctrine so much as reformulate it.

129. Id. at 291.

130. Id. at $78-81$.

131. Id. at 301.

132. Unger, supra note 13, at 577.

133. See id. Much of the motivation for Sadr's exposition on economics as doctrine and not science is to debunk the notion propounded by the Marxists of his day that historical forces drive political and economic developments according to ironclad laws of nature, thereby making economics almost a form of natural science. See, e.g., IQTISADUNA, supra note 7, at 78-81 (responding at length to these assumptions as concerns power over the means of production). It also bears mentioning that Sadr's relative ignorance of capitalist systems is partially betrayed in this section, as he incorrectly understands capitalist systems to justify themselves exclusively in the same political, normative, and ideological manner as he describes Islamic economics, rather than as uniquely in conformity with immutable and universal aspects of human nature. Compare id. at 291 (describing the similarities of capitalism and Islamic economics as being ideologically driven and not scientific in nature), with Unger, supra note 13, at 576 (assailing the law and economics movement for developing doctrines that purport "to discover a canonical form of social life and personality that could never be fundamentally remade”). 


\section{B. Neutral Role for Shari'a in a Functional System}

\section{Shari'a as Limitation}

Early in Iqtisaduna, Sadr indicates that the shari'a must play a role in curbing certain types of economic activity within the state, thereby suggesting faith in an objective component to the shari'a separate from political and ideological debate. Sadr delineates two types of limitations to economic freedom that exist in his economic system, the first of which is internal to each individual actor, and the second external. ${ }^{134}$ Respecting the internal limitation, Sadr, like Unger, believes that institutions and systems of human association affect human behavior. ${ }^{135}$ Unger, for example, suggests that the American system has been designed to further the notion that in economic affairs humans are to act in the "harshest self-interest" while as family members they do not. ${ }^{136}$ Unger argues that alternative forms that do not so starkly bifurcate between the personal and the commercial are possible. ${ }^{137}$ For Sadr, in a suitably designed Islamic system, actors would not pursue their self-interest to such extremes either. Rather, their subjective impulses, informed by the ethos of the overarching Islamic system, would lead them to behave less avariciously. ${ }^{138}$

Sadr is not so naïve, however, as to imagine that subjective impulses in a differently designed system would be entirely sufficient to rein in exploitative or rapacious conduct among all commercial actors in the commercial sphere. Much as Holmes saw the function of the law as being to constrain the "bad man,"139 Sadr invokes the external limitations of the law to supplement these internal limitations. The legal, external

134. Sadr's terms in Arabic for the internal and external limitations, dhati and maudhu'i, are often translated, respectively, as “subjective” and “objective.” In fact, I later translate Sadr's extensive use of the term dhatiyya as "subjectivity." In this context, however, a similar translation would be inaccurate. As will be seen, Sadr's two examples of external limitations are those imposed by a political leader and those imposed by the shari' $a$, and, quite clearly, the rulings of a political leader acting alone can hardly be described as "objective." Rather, the idea is that, in Sadr's words, the external limitations are "imposed by an outside force" in contradistinction to internal limitations, which "arise from the depths of the soul." See IQTISADUNA, supra note 7, at 260.

135. See id. at 260-62; Unger, supra note 13, at 622-24.

136. See Unger, supra note 13 , at 622-24.

137. See id. at 624-25.

138. IQTISADUNA, supra note 7, at 260-62.

139. See O. W. Holmes, The Path of the Law, 10 HARV. L. REV. 457, 459-60 (1897). 
limitations take two forms, those of the shari' $a$ and those implemented by the Holder of Command. ${ }^{140}$

The limitations on economic activity imposed by the Holder of Command as political leader are to constrain private enterprise by exercising a generally regulatory and supervisory authority in order to further the broader public interest and the objectives of the Islamic economic regime. ${ }^{141}$ The Holder of Command's role, therefore, is akin to ordinary regulation and lawmaking, dominated as it would be by conventional political considerations.

These ordinary regulatory constraints, however, are limited by the higher law of the shari'a. ${ }^{142}$ The ordinary political process could result in lawmaking and regulatory authority intended to serve particular functional ends, but the shari'a would impose limitations on that process, much as the Constitution imposes limitations on the regulatory and lawmaking authority of Congress. For example, Sadr indicates that the Holder of Command could not permit riba, fraud, or void the inheritance law, but the Holder of Command could impose policies respecting the extraction of minerals, irrigation, and agriculture that do not conflict with the shari'a. ${ }^{143}$

\section{Shari'a as Signpost}

According to Sadr, the legal rules that underlie the economic system are similar to the top floor of a two story structure, with the economic principles being the bottom floor. ${ }^{144}$ To understand the system, one must examine the legal rules carefully, and from this, the economic policies and principles can be "discovered." "145 The shari'a thus serves an important role in addition to providing the framework within which politics and lawmaking must operate; it is also the means by which broader economic objectives are "discovered." It therefore both constrains ordinary lawmaking while also providing the bases upon which Islamic policies may be found.

\footnotetext{
140. IQTISADUNA, supra note 7, at 262.

141. Id.

142. Id. at 263.

143. Id.

144. Id. at 348 .

145. Id.
} 


\section{Functional Jurisprudence}

\section{Assault on Formalist Hermeneutic Respecting the Scope of Hadith}

Though Sadr attributes a great deal of importance to shari'a, Sadr's idea of shari'a is a functional one. Sadr immediately follows his disquisition on objective limitations of the shari'a with evidence setting forth the entirely radical position that Muhammad's adjudicatory (qadha') rulings, as opposed to his religious (nahi) determinations, were not part of the shari'a and did not constitute limitations on the activities of a future Holder of Command. ${ }^{146}$

The consequence of Sadr's position should not be gainsaid; it is a direct and unambiguous assault on the sanctity of the most important source of law within the hermeneutic, the hadith. It effectively permits in many cases a Holder of Command to make a temporal political determination entirely inconsistent with an action, statement, or utterance of Muhammad. ${ }^{147}$ Moreover, this position largely removes the restraint of the hadith in the context of commerce, where determinations of which hadith are religious in nature and which are regulatory or adjudicative is almost impossible in many cases. That is, a jurist could be fairly certain that a hadith requiring the believers to pray in a particular manner related to Muhammad's role as Divine Messenger, but how can one determine whether Muhammad's prohibition against the sale of uncaught fish, ${ }^{148}$ for example, was religious in nature or merely some sort of rule instituted by the Holder of Command relating to a practice that did not seem to be serving public interest at the time? This distinction

\footnotetext{
146. Id. at 263-64.

147. Sadr's work was subject to rather vituperative attacks on this basis, among which were accusations of heresy. See MALLAT, supra note 5, at 143 (describing two critical reactions to Sadr's work). That said, it is also representative of one of the most creative contributions of modernist Muslim intellectuals to the development of the shari'a in the contemporary era. Beyond Sadr, reformists from the feminist Fatima Mernissi to Fazlur Rahman have cast doubt on the historicity of the hadith, deriving from their conclusions varying views concerning the proper role of the hadith in the hermeneutic. See, e.g., FAtima Mernissi, The VeIl AND THE MALE Elite: A FEMINIST INTERPRETATION OF WOMEN'S RIGHTS IN ISLAM 44-61 (Mary Jo Lakeland trans., Adison-Wesley Publ'g 1991) (1987) (suggesting that a heightened skepticism toward the accuracy of the hadith would lead to a more faithful, and more salutary, understanding of the rights of women under the dictates of Islam); FAZLUR RAHMAN, ISLAM 43-67 (2d ed. 1979) (acknowledging defects concerning the historicity of the hadith and suggesting that, because they seem to be accurate reflections of the period in which Muhammad lived if not what he said, they create a generalized "ethos" to which to adhere rather than a set of separate, permanently binding rules).
}

148. See Section I.B, supra. 
calls into question vast numbers of hadith that could alternatively be viewed as either regulatory or religious depending on the ideological biases of the interpreter.

\section{Role of Subjective, Ideological Choice in Deriving Shari'a}

The question therefore remains, in light of the important dual role the shari'a was to play as signpost and as limitation, precisely how to determine the contours of the shari'a. If the content of the shari'a was as subject to ideological bias as it appeared to be absent certainty over the binding nature of the hadith, is there any objective and neutral process that could be utilized to determine what the rules of the shari'a are? Sadr struggles at length with this question, contrasting ijtihad, from which the mujtahid can objectively derive the shari'a, with subjectivity (dhatiyya). ${ }^{149}$ The term ijtihad has a long and storied history within both Sunni and Shi'i jurisprudential thought, but it is generally meant to signify the proper application of juristic effort to derive a legal rule. Thus, the term more than anything delineates parameters of interpretive legitimacy without specifically defining them. Ijtihad leads to the proper set of legal rules whereas unfettered subjectivity is its opposite, either failure to develop the proper rules or the development of improper ones.

Yet when describing what he dismisses as excessive subjectivity as opposed to ijtihad, Sadr falls immediately back onto his ideological biases. He identifies four subcategories of "subjectivity." First, there is the justification of reality (tabrir al-waqi'), whereby a jurist mistakenly changes specific rules to fit contextual reality rather than altering that reality through the establishment of alternative forms of human association. ${ }^{150}$ Sadr's paradigmatic example of this type of subjectivity is an attempt to exempt interest on debt from the prohibition of riba. ${ }^{151} \mathrm{~A}$ second form of subjectivity involves a jurist evaluating a rule from a nonIslamic framework with which he is familiar and ignoring that rule when not in accordance with the framework in question. ${ }^{152}$ Sadr's example here is the reluctance of some jurists to set limits on private ownership of property despite the existence of significant limitations within the shari'a, with no basis for failing to do so other than that it does not harmonize within a non-Islamic economic framework. ${ }^{153}$ Third, Sadr

149. See IQTISADUNA, supra note 7, at 357-60.

150. Id. at 360-61.

151. See id. at 361.

152. Id. at 361-64.

153. See id. at 362 . 
indicates that jurists may subjectively divorce (tajreed) a rule from the social and political context in which it was made, thereby achieving a perverse result. ${ }^{154}$ For example, Muhammad may have failed to object to commercial activities wherein a laborer received a fixed wage rather than a share of profits, but the circumstances of Muhammad's tacit acceptance in seventh century Medina could not possibly be extended into the world of twentieth century commerce, where miners in an oil company were extracting enormous amounts of wealth from the earth for the benefit of other parties without a right to any profit in the material extracted. ${ }^{155}$ The fourth and final type of subjectivity is prejudging the interpretation of a text based on preconceived notions rather than objective ijtihad. ${ }^{156}$ Sadr's example was of jurists who failed to distinguish between Muhammad's role as Prophet and as judge and the implications concerning the binding nature of his speech depending on which role he was fulfilling. ${ }^{157}$

Sadr's categories hardly solve the problem of excessive subjectivity; if anything, they demonstrate what appears to be the unconstrained manipulability of doctrine. Sadr maintains, for example, that exempting bank interest from the riba prohibition is a "justification of reality," Sadr's first category of illegitimate subjectivity. A jurist more sympathetic to the ideological and political principles underlying free market economics could almost as readily use Sadr's classifications to argue that Sadr's extension of riba into the realm of commercial bank debt was subjectively divorcing a rule from its social and political context (the third category of subjectivity) and that, in suggesting that laborers must be entitled to a share in profits, Sadr was subjectively and illegitimately ignoring a clear legal rule concerning the permissibility of hired labor that did not harmonize within his own conceptual framework (the second category of subjectivity). There does not appear to be any way to determine the proper use of ijtihad from the improper exercise of subjectivity.

It is a mark of Sadr's brilliance that despite his considerable distance from debates of this kind in the American context, he fully grasps the consequences of his ijtihad-subjectivity theory and makes entirely clear that subjectivity and ideological choice are an inevitable part of interpretation. Sadr argues that in deciding amongst competing interpreta-

154. See id. at 364-69.

155. Id. at 366-67.

156. Id. at 369-70.

157. See id. 
tions of Islamic sacred text, at times a subjective ideological choice is made that reflects the precise, Islamic form of human association the jurist prefers. ${ }^{158}$ He thus proposes the radical notion that if a particular ruling reached by other jurists appears to conflict with the functionality and goals of the economic system generally envisaged by the jurists, it would only be logical for the jurists to dismiss the ruling on that basis alone and adopt an alternative ruling. ${ }^{159}$

Importantly, however, Sadr, unlike Unger, believes that objective, nonpolitical interpretation can exist despite the obvious and inevitable role of subjectivity. ${ }^{160}$ Indeed, the dual role that he places upon the shari'a, to inspire ordinary lawmaking even as it constrains it, requires some level of neutrality and distance from ideological and political choice to be taken seriously. ${ }^{161}$ Nevertheless, aside from his less than helpful four categories of subjectivity, Sadr is vague on setting the parameters of legitimate ijithad other than to say that it must fall within a set of "general rules" (al-shurut al-amma) that governs the exercise. ${ }^{162}$ This creates a considerable amount of confusion as to precisely how the shari'a can function in the neutral and objective way that Sadr envisions.

\section{Functionalism in Application-The Prohibition of Hired Labor}

The relaxation of Langdellian formalism was central to Sadr's ability to make the economic system he described functionally coherent. Islamic economics, as described by the vast majority of modern commentators, by contrast, lacks such coherence. It has developed a theory of social order that is highly mutual in conception and that uses notions of mutuality to justify the two central prohibitions of traditionalist Islamic finance, those of interest and speculative risk without carrying them through to their logical conclusions. Essentially, the theory is that within any given transaction, the creation of circumstances where one party may earn a return while her partner in the same enterprise or endeavor may suffer a significant loss is damaging to social harmony and should

158. See id. at $370-78$.

159. See id. at 370-71.

160. Compare id. at 357-60 (delineating the role of ijithad as against subjectivity), with Unger, supra note 13, at 564-65 (suggesting the impossibility of an interpretive process that was not at its core a political argument).

161. See Section III.B, supra.

162. See id. 
be prohibited. ${ }^{163}$ In the words of Sayyid Qutb, one of the most prominent early theorists of Islamic economics: ${ }^{164}$

Anyone who extends to me one dinar in order to receive a return of two dinars from me is my enemy; I will not wish him well, nor can I regard him in amity. Mutual support (ta'awwun) is one of the fundamental principles of Islamic society, but riba destroys this sentiment and weakens its foundations. For this reason does Islam despise riba. ${ }^{165}$

A similar position is maintained with respect to the prohibition against excessive speculation; the potential gain is unearned, in the sense that it is acquired solely at the expense of other parties to the endeavor, which is destructive to social harmony. ${ }^{166}$

This position devolves into incoherence, however, when the Langdellians that dominate Islamic finance insist on the permissibility of hired labor because Muhammad seems to have at least implicitly approved the practice under the doctrine of 'ijara, or rent for hire. ${ }^{167}$ Hired labor quite obviously does not involve values such as mutual help and fellowship. As a general, conceptual matter, hired laborers, like creditors, earn a fixed return that is not related to the success of the venture. The employer is legally required to pay its employees wages even if the employer suffers losses, and the employer is not legally obligated to pay more if the employer's profits are unusually large. ${ }^{168}$ In Sadr's context, a large amount of hired labor was devoted to the oil industry, and Sadr believed that very high profit levels were likely to be maintained for a considerable period of time in that industry. ${ }^{169}$ As a result, Sadr clearly thought that the fixed return in the labor context was to the detriment of the party receiving it, in this case the laborer, and, in any event, in his

163. See, e.g., QUTB, supra note 6, at 103 (suggesting that debt-based relationships deny the natural Muslim inclination towards mutual support and kindness); Kuran, supra note 11, at 17175 (describing numerous Islamic economists as having such a view).

164. See note 6, supra.

165. QUTB, supra note 6, at 103.

166. See Kuran, supra note 11, at 175 (describing the position of Islamic economists on the policy underlying the speculation ban). Qutb also specifically mentions the Qur'anic injunction against gambling, from which the speculation prohibition is derived, as being "incompatible" with the spirit of love (mawadda), mutual aid (ta'awun), and brotherhood ('ikha') that Islam was meant to propagate. QUTB, supra note 6, at 98.

167. Kuran, supra note 11, at 174 (indicating general permissibility of hired labor).

168. Timur Kuran has made precisely this criticism in his survey of contemporary Islamic economics. See Timur Kuran, The Economic System in Contemporary Islamic Thought, 18 INT'L J. MidDLE E. STUD. 135, 153-54 (1986).

169. See IQTISADUNDA, supra note 7, at 362-63. 
view, the practice was violative of the mutuality principle and his own ideas of social justice and deserved abrogation.

Sadr removed the inconsistency with respect to mutuality in employment, at least in the context of mining for precious minerals, by prohibiting hired labor, but, given the existence of a hadith suggesting the permissibility of hired labor, he required a willful abrogation of the traditionalist interpretive system to do this. He simply indicated that the rule permitting hired labor was taken out of context, that seventh century Medina did not permit labor to be sold in the manner that it is in contemporary society in the context of precious mineral mining, and that, in any event, the Prophetic permissibility could be without basis despite ample authority in support of it. ${ }^{170}$ Given Sadr's theory, discussed above, that determinations of other jurists could be ignored if they did not fit well within the functionality of an Islamic economic framework, this conclusion would not be difficult for Sadr to reach no matter how much juristic authority existed to oppose it.

In the end, Sadr's revolution proved to be a failure. Islamic finance has abandoned its revolutionary economic roots, even in the one state that was most enamored of Sadr's ideas, Iran. ${ }^{171}$ Sadr's role, however, in bringing the jurists back from irrelevancy in the economic sphere should not be understated. The impact of Iqtisaduna has been extraordinary and the work has played a significant role in Islamic economic and financial revivalism in many Muslim societies. ${ }^{172}$ Whether this momentum can be sustained depends on the extent to which Sadr's revolutionary ideas, properly understood, can be suitably adapted to serve the contemporary era in a considerably less ambitious manner. If it cannot, then Islam will, instead, return to increasing irrelevancy in the commercial context through its continued insistence on Langdellianism. Before addressing the basis for adapting Sadr's jurisprudential flexibility to the contemporary era, however, I first turn to Professor Jackson's comparisons of Islamic interpretive theory to Unger's version of Critical Legal Theory, in order to lay the groundwork for a more complete explanation of Sadr's theory on the nature of shari'a.

170. See id.

171. See RoY, supra note 32, at 140-41.

172. MALLAT, supra note 5, at 142-43. 


\section{UNDERSTANDING THE JURISPRUDENTIAL IDEAS OF IQTISADUNA}

\section{A. Alternative Approaches to Sadrism}

Professor Jackson's groundbreaking thesis that Islamic interpretive theory may not be the source of any Islamic doctrine but rather the source of its validation has some resonance in Sadr's context. This Article has already demonstrated some modest similarities between Unger's theories, explored at length by Professor Jackson, ${ }^{173}$ and Sadrist ideologically-driven economic philosophy. Professor Jackson's essay moves from Unger to examine Islamic doctrine in comparison to the work of Professor Fish, who has argued that doctrine merely validates preconceived political and ideological presuppositions and biases and that the extent to which a particular interpretation is viewed as valid is merely an indication of its rhetorical strength and its level of harmonization with commonly accepted and entirely contextual understandings, norms, and objectives. ${ }^{174}$

Jackson's implicit claim, given his invocation of theorists who deny any notion of objectivism in legal interpretation, seems to be that no objectivity is to be found in the interpretation of Islamic texts. I do not address this matter, however, as I find little benefit to revisiting a debate in the Islamic context that has been exhaustively conducted among American scholars of jurisprudence. More importantly for purposes of this Article, however, there is virtually nothing to be gained from this approach as a prescriptive matter. The analysis cannot plausibly be extended to address doctrinal reform. There are two possible prescriptive positions that could be developed from Jackson's approach and both are laden with substantial difficulties.

The first approach would be to adopt Unger's thesis that doctrine is a means of illegitimately narrowing ideological, ethical, and political argument. The logical consequence would then be to seek to expand doctrinal debate beyond its currently narrowing confines through a ceaseless attack on any notion of neutrality and objectivity in the process of legal interpretation or on any suggestion that there is a sphere within which the legal process operates that is separate from the political. Professors Dorf and Issacharoff point out that a similar approach is less than effective in the American context to those interested in having their

173. See Jackson, supra note 15 , at 182-85, 192-94.

174. See id. at 195-97. 
views considered by the institutions involved in adjudication. ${ }^{175}$ They indicate, for example, that a "radical" legal realist could not logically criticize the decision of Bush v. Gore as excessively political because under the paradigm of that type of realist, the institution would only be acting in the overtly political manner that, according to such a theorist, it always did. ${ }^{176}$ Moreover, none on the Court would be likely to take this type of broad and universal criticism seriously, as it would undermine altogether the work they were doing. ${ }^{177}$ Dorf and Issacharoff conclude that these sorts of attacks may delegitimize institutions, some of which may well deserve to be delegitimized in this manner, but any academics more interested in serving a "checking" function that might influence the Court in a more positive direction would do well to eschew such an approach in favor of more "sympathetic" criticism. ${ }^{178}$

Surprisingly, Jackson does not seem to realize the extent to which an approach that calls upon the ideas of Unger and Fish necessarily dismisses and delegitimizes as delusional exercises in "transcendental nonsense" 179 efforts of Islamic scholars and jurists of virtually any persuasion to interpret religious text faithfully and objectively. Jackson concludes his essay with the hope that those who might view his work as "juristic nihilism" realize that law and the government upon which it is based is "no better, no worse, no more and no less Islamic, than the men and women who authenticate them." ${ }^{180}$ It is hard to imagine that any jurists would subscribe to the view that the Qur' an carries no separate and independent meaning of its own of any kind and that it is therefore in need of juristic "authentication.” Dorf and Issacharoff correctly note that the Supreme Court is not likely to be influenced by those that delegitimize it as an institution, but it is even more difficult to believe that very many Muslims, jurists or otherwise, who take Islamic doctrine seriously will be swayed by an approach that strips their holy texts of all objective, legal meaning and supplants in their place ideological, political, and ethical presuppositions and biases that would exist irrespective of whether or not Revelation ever happened.

The other prescriptive position that could be developed from Jackson's work would lean less towards Unger's ideas and more towards

175. See Dorf \& Issacharoff, supra note 16 , at 948 .

176. See id.

177. See id. at $948-49$.

178. See id.

179. See generally Felix S. Cohen, Transcendental Nonsense and the Functional Approach, 35 Colum. L. REV. 809 (1935).

180. See Jackson, supra note 15 , at 200-01. 
those of Fish. This position would suggest that while doctrine, and the legal theory under which it is developed, may be everything that Unger decries, its role in seeking to limit and defuse ethical and political debate within any social construct is in fact beneficial to social harmony. This benefit of the law, however, presupposes a certain level of deception of the believers, in that legal theory would hardly serve the role of defusing debate if everyone knew perfectly well it was simply rhetorically enhanced political argument. This places the commentator seeking to move Islamic doctrine into more positive directions in a dilemma. The commentator could indicate that Islamic legal theory was rhetorical etiquette, in which case the commentator's position would be disregarded for the reasons set forth in the previous paragraph, and, to the extent it was not, the commentator would destroy the salutary role that doctrine is supposed to fill. Alternatively, eager to preserve this salutary role of doctrine, the commentator could make criticisms of doctrine without disclosing her underlying conviction that the doctrinal positions cannot possibly be derived from legal theory. This approach is deeply problematic, however, and seems insultingly patronizing to those who endeavor mightily and sincerely to understand God's word as objective and neutral reality and not the product of "authentication."

\section{B. Shari'a and the Interpretive Community}

In the absence of the marja'iyya, Sadr's ideas seem to be less than persuasive and, if anything, an implicit vindication of Professor Jackson's views. Sadr insists on an objective, neutral and nonpolitical role for the shari'a both to inspire legislation as well as to constrain it, but then subsequently demolishes a series of received notions concerning hadith that might help establish some form of quasi-scientific objectivity in the jurisprudence. He acknowledges the influence of subjective ideological and ethical conviction, but insists that ijtihad has a role to play through the imposition of unspecified "general rules" that will guide the interpretive process. The result is largely salutary, a functional jurisprudence that achieves recognizable social ends, but seems, if anything, to fortify the position that the shari'a can have no certain neutral, nonpolitical and nonideological content given the absence of any basis upon which such neutrality might lie.

The existence of an institution, however, that acts as the Hidden Imam's deputy and is therefore the caretaker of the shari'a leads to an entirely different conclusion. Sadr clearly accepts some role for subjectivity and dismisses any necessitarian notion that the law can be derived 
like a science, but he believes that the marja'iyya can reformulate the jurisprudence along functional and ideological lines, redefine the goals of the shari'a, and then place objective and neutral bounds on the interpretive process to ensure continued adherence to these goals. Contrary to the reductive and verifiably false cliché that religious law cannot be amended because it is written by God, Sadr seeks to persuade the marja'iyya to adopt precisely such an amendment through a new understanding of which Prophetic statements, utterances, and tacit acceptances are a binding part of the shari'a and which parts are not. Moreover, he reworks doctrine substantially to create a new understanding of the shari'a principles that is deeply functional, communitarian, mutualistic, and egalitarian in its nature and that emphasizes those elements of Islamic history that focus on ideals of mutuality, egalitarianism, and social justice. He is entirely aware that his theories on their own are largely the subjective ideological convictions of a scholarly revolutionary. When these convictions are, however, adopted by the institution that acts in the absence of the infallible Hidden Imam, they become the shari'a under the rules of Shi'ism, with the marja'iyya then establishing the objective and neutral bounds within which the interpretive process would operate to derive further and more specific constraining interpretive rules in pursuance of it.

Sadr's approach, despite its obvious heterodoxy, is deeply Islamic in nature. Sadr claims that the objectives he delineates can be found in the classical period of Islamic history in the form of fairer rules of economic association. They owe their origins, he argues, to statements of Muhammad relating to the equality of human beings. It is a highly stylized narrative, in other words, in which Islamic principles are invoked to overhaul Islamic doctrine and the traditionalist Islamic approach to jurisprudence, much in the manner that President Lincoln, for example, grounded his norms and principles of equality in America's dawn as set forth in the Declaration of Independence. ${ }^{181}$

Seen in this light, Sadr's claims to history are entirely sensible. Professor Mallat criticizes Iqtisaduna for its ahistoricity concerning the importance of egalitarianism and social justice in Islamic history, ${ }^{182}$ but this is beside the point. Sadr is aware of the historical evidence of poverty and exploitation in the classical period; he does not seek to deny it, ${ }^{183}$ so much as tell a compelling and transformational narrative that

181. FLETCHER, supra note 29, at 36-37.

182. See MALLAT, supra note 5, at 147.

183. Professor Mallat accepts this, though he does not seem to be able to reconcile Sadr's 
emphasizes and highlights a particularly egalitarian strain of jurisprudence that focuses on social justice, the origins of which clearly lie in Islam's dawn. President Lincoln, we may assume, was well aware when delivering the Gettysburg address that the words he uses to denounce slavery were taken from a document written by a slaveowner, but this does little to detract from his claim that the proposition that all men were created equal comes not from him, but from the document that declared the United States a free and independent nation. The respective narratives may be stylized and ahistorical, but they are powerful nonetheless.

In the end, Sadr's faith in the marja'iyya acting as the infallible Imam's deputy liberates him from Langdellian legal science and allows him to espouse such radical jurisprudential notions. The same cannot be said, however, for his counterparts in Sunni Islam, with its absence of comparable jurists of equivalent theological stature in the contemporary period. As a result, within the Sunni world, the notion of bias or ideological presupposition in the interpretation of text is inherently more destabilizing.

It is to Professor Jackson's credit that he has identified precisely this problem of the absence of an authoritative interpretive community in his extensive work in the Sunni context. For example, Professor Jackson correctly notes that the feminist scholar Fatima Mernissi has presented an interpretation of Islamic text and history concerning the rights of women that could be seen as plausible and yet radically different from traditional interpretations. ${ }^{184}$ In the absence of an authority, it is difficult to determine which interpretation would be deemed more legitimate. Professor Jackson's work demonstrates convincingly that Sunni Islam addressed this problem at the end of the first millennium through a prohibition against the exercise of interpretive effort to derive alternative rules from foundational text and the consecration of particular schools of thought (madhahib) - the fabled "closing of the door of ijtihad."185 The intent was not to prevent the evolution of doctrine at all, but, as Jackson suggests, to establish particular schools of authority to which doctrine had to refer to establish its legitimacy. ${ }^{186}$

In any event, the dissolution of the schools of thought in the Sunni world has led to considerable confusion and uncertainty, resulting in a

awareness of the ahistoricity of his claims with his repeated references to classical rules. See id.

184. See JACKSON, supra note 22, at 74; MERNISSI, supra note 147.

185. See JACKSON, supra note 22, at 73-83.

186. See id. 
preoccupation by Sunni Islamic movements with efforts at codification of supposedly historic rules, so that interpretive control is provided by a text rather than an institution. ${ }^{187}$ Sunni theorists engaging in Islamic economics have, in light of this, demonstrated considerable reluctance in developing functional jurisprudence despite their inherently functional objectives. The militant Sayyid Qutb, for example, in an earlier edition of his work on economics and social justice, allowed for a comparatively large role for masalih al-mursala, or public interest, in developing jurisprudence, but he later removed much of this. ${ }^{188}$ Qutb's reluctance to engage in open-ended, potentially useful interpretive techniques no doubt stems from his inherent distrust of jurists. In some of his works, he openly muses about the possibility that a juristic community could betray what he regarded as true Islamic doctrine. ${ }^{189}$ To allow jurists to develop the shari'a with such expansive interpretive tools as public interest was thus dangerous to Qutb in a manner that it was not to Sadr.

In short, Qutb had no faith in his interpretive community, and this hampered his ability to call for a similarly reformulated jurisprudence. Instead, he insisted on the necessity of a functionally distinct Islamic economic system with comparatively little explanation of the jurisprudential means by which it might arise. ${ }^{190}$ This flaw found itself replicated in the practice of Islamic finance, where, like Qutb, proponents preach fairness and social justice endlessly, but, when forced to apply the formalist methodologies in a manner that Qutb was never required to, fall back upon a traditionalist and formalist practice in which these functional concerns play an exceedingly minor role.

\section{WHITHER ISLAMIC FINANCE?}

While a purely descriptive analysis of the jurisprudential origins of Islamic economics may have merits on its own, a question does remain as to whether there is anything that might be learned from Sadr's theories that has relevance in the contemporary world. I maintain that there is considerable room to reform Islamic finance along the functional

187. JACKSON, supra note 22, at Xvi-xviii; see also LOMBARDI, supra note 82, at 67-69 (describing the decline of the madhabs within the specific context of Egypt).

188. See Algar, Introduction to QUTB, supra note 123, at 16-17.

189. See, e.g., MALLAT, supra note 5, at 64 (quoting 2 SAYYID QUTB, FI ZILAL AL-QUR'AN [IN THE SHADE OF THE QUR'AN] (new ed. 1973)).

190. See generally Algar, Introduction to QUTB, supra note 123. 
lines envisaged by Sadr so as to make the practice more relevant and salutary to the lives of contemporary Muslims.

\section{A. Current Practice}

Currently, in the words of the eminent Islamic theorist Seyyed Hossein Nasr, Islamic economics is "caught in the intellectual web of the very system it set out to replace" and is no longer a truly independent discipline, defining itself almost exclusively with reference to its Western counterpart. ${ }^{191}$ The sole remnant of the Islamic economy lies in the area of Islamic finance, which does not seek social, cultural, and economic revolution, but rather preaches a narrow adherence to traditionalist notions of the shari'a solely in the banking sector. ${ }^{192}$ Given the substantial difficulty of maintaining a financial institution that neither took interest on commercial loans nor engaged in the types of commercial uncertainty banned by the doctrine of gharar, Islamic financial institutions have fallen back upon stratagem and artifice in order to function, of which two large and illustrative examples are the murabaha and takaful.

The murabaha is an Islamically permissible form of short-term financing designed to avoid interest wherein the financial institution agrees to purchase an item on behalf of a client and then sell it to the client on the basis of an agreed markup, with payment always coming at

191. See Seyyed Vali Reza Nasr, Islamization of Knowledge: A Critical Overview, 30 ISLAMIC STUD. 387, 388 (1991); see also El-Gamal, supra note 3, at 123.

192. RoY, supra note 32, at 140-41. Roy also notes that in some nations, particularly Saudi Arabia and Pakistan, a conservative trend always existed among some jurists to remake the banking sector along largely formal lines rather than transform the societies of the Muslim communities in which they operated. See id. This may well be true at some lower level, but the dramatic influence of the revolutionaries on the rise of Islamic finance cannot be gainsaid. For example, in the case of Pakistan, one of the two nations where this more conservative brand of Islamic finance developed, the nation's most influential Islamist, Syed Abul Al'a Mawdudi, was an unabashed revolutionary. See note 3 and accompanying references, supra. In addition, one of the most popular and prominent defenders of contemporary Islamic finance in Pakistan, Judge Usmani, speaks extensively on the social justice issues raised by Mawdudi in the context of finance. Compare SAYYed ABUlala MAUDOODI, ECONOMIC PROBLEM OF MAN AND ITS ISLAMIC SOLUTION 2728 (M. Abdul Waheed Khan trans., 2d ed. 1955), with MUHAMmad TAQI Usmani, AN INTRODUCTION TO IsLAMIC FINANCE 9-10 (2d ed. Kluwer Law Int'l 2002) (1998) (each discussing the manner in which bank interest is a cause for unjust wealth disparities). Umar Chapra, another outspoken advocate of the role of social justice in Islamic finance, was employed by the Islamic Research Institute of the Islamic Development Bank, which operates in Saudi Arabia. See generally UMAR CHAPRA, TOWARDS A JUST MONETARY SYSTEM (1985). Saudi Arabia is Roy's second example of a nation that espouses a distinctly formalist approach to Islamic finance. See also El-Gamal, note 3, at 122 (describing the revolutionary Islamic economic movement as being the genesis of Islamic finance). 
a later time and the markup always reflecting a prevailing interest rate. ${ }^{193}$ If, as is often the case, the item in question was readily fungible, such as the stock of a large and relatively stable corporation, the transaction resembled a debt transaction in all but form. In a particularly egregious and increasingly popular form of murabaha financing known as tawarruq, the asset in question is a commodity that is resold to an original seller. The borrower "buys" the commodity from an Islamic financial institution which itself bought it from the original seller. The borrower then incurs an obligation to pay for the commodity in the future an amount that reflects the prevailing interest rate, and then simultaneously sells the commodity back to the original seller at the price it was originally sold, less fees. ${ }^{194}$ The commodity might not have even left the original seller's possession. By one commentator's recent estimate, as much as $95 \%$ of the investments of Islamic financial institutions take the form of the murabaha. ${ }^{195}$

Takaful is the formal means by which insurance is conducted notwithstanding the Islamic prohibition against gharar. Takaful derives from the determination by some scholars that gratuitous contracts are not subject to the gharar prohibition. ${ }^{196}$ Pursuant to takaful, a group of Muslims agrees to protect one another in the case of casualty or loss by "gratuitously" pooling their resources through making regular, contractually required payments in the form of premiums to be invested in Islamically acceptable commercial products. ${ }^{197}$ When a casualty or loss occurs, the participants each "gift" a portion of the premiums (and any undistributed profits) theretofore collected to the bearer of the loss pursuant to the terms of a binding contract. ${ }^{198}$ Whether this exercise in artful semantics can be described as formalist is highly questionable; there

193. VOGEL \& HAYES, supra note 62, at 140-41.

194. Mahmoud A. El-Gamal, Limits and Dangers of Shari'a Arbitrage, http://www.ruf.rice.edu/ elgamal/files/Arbitrage.pdf at 9 (last visited Oct. 9, 2007) (describing this as a prevalent practice within the banks of the Gulf Cooperation Council, a coalition of six Arab nations located in the Persian Gulf region that includes Saudi Arabia, Kuwait, and the United Arab Emirates).

195. See Ibrahim WARde, Islamic Finance in the Global ECONOMY 133 (2000). It should be noted that some formalists are not entirely comfortable with the especially transparent forms of murabaha, involving, for example, fungible products, entirely simultaneous transfers, or tawarruq. See, e.g., UsMANI, supra note 192, at 152-53 (describing the murabaha as "borderline”); El-Gamal, supra note 3, at 128.

196. VOGEL \& HAYES, supra note 62, at 151-52. For a classical reference, see 2 IBN RUSHD, supra note 51, at 361 ("[A]ll which cannot be sold legitimately from the standpoint of gharar [may be gifted].”).

197. VOGEL \& HAYES, supra note 62, at 151-52.

198. Id. 
is little other than terminology that separates the takaful from conventional forms of insurance.

Despite this highly formal practice which relies on such artifice, the language of Sadr and Qutb respecting mutuality, social justice, and fairness in Islamic financial practice is widely repeated by large numbers of the defenders of Islamic finance, suggesting that the desire for achievement of the original functional objectives of the revolutionaries remains strong within the Muslim community. ${ }^{199}$

I have written elsewhere about the several problems arising from formalist practice. ${ }^{200}$ These include hypocrisy by proponents who emphasize the importance of mutuality, partnership, and fairness in finance and commerce and then employ practices such as tawarruq. ${ }^{201}$ There has, in addition, been a failure to develop a formalist solution to many existing commercial problems, which are currently addressed by contracting in violation of the shari'a and selecting New York or English law to govern the supposedly "Islamic" transaction. ${ }^{202}$ Professor ElGamal adds others, such as the fact that the extensive and sophisticated multiparty transactions necessary to sustain tawarruq transactions resemble those of money launderers and terrorist financiers and therefore are easily susceptible to dangerous forms of abuse. ${ }^{203}$

199. See Kuran, supra note 11, at 173, 174 (describing the prohibition of interest, grounded on the principle of fairness, as being "the most celebrated" injunction in Islamic economics among the proponents of the discipline).

200. See Hamoudi, supra note 39, at 615-19.

201. Id.

202. Id. at 618 (citing Umar F. Moghul \& Arshad A. Ahmed, Contractual Forms in Islamic Finance Law and Islamic Inv. Co. of the Gulf (Bahamas) Ltd. v. Symphony Gems N.V. \& Ors.: A First Impression of Islamic Finance, 27 FORDHAM INT'L L.J. 150, 189-90 (2003)); see also VOGEL \& HAYES, supra note 62, at 144-50.

203. See El-Gamal, supra note 194, at 11-12. The most prominent functionalist addressing the topic of Islamic finance has been Professor El-Gamal, who has admirably argued for a mutual structure for Islamic banks and insurance schemes wherein the policy holders or the depositors, as the case may be, are themselves the owners of the nontransferable shares of the institution to the extent of their deposits or policies. See, e.g., Mahmoud A. El-Gamal, Mutuality as an Antidote to Rent-Seeking Shari'a-Arbitrage in Islamic Finance (2005), http://www.ruf.rice.edu/ elgamal/files/Mutuality.pdf [hereinafter Mutuality]. Professor El-Gamal argues that the mutual form helps serve what he calls the "spirit" of the riba and gharar restrictions, namely avoidance of inequity and excessive risk taking in commercial transactions, because mutual structures are not exclusively designed to maximize profit for shareholders at all costs and so are less likely to induce managers to take excessive risks given that there is no stock price that will rise or fall as a result of any actions they take. See id. at 5-7. El-Gamal does not object to the formalism that infects the current practice; indeed, he argues for its expansion to deal with the deposit side of the institution as much as its asset side, see El-Gamal, supra note 3, at 136, but he wants to see in the process the banks achieve what he views as the ultimate purposes of the shari' $a$, which he regards as more important than merely using artifice to evade restrictions. $\mathrm{Mu}$ - 
The central, ontological problem, however, is that the roots of Islamic finance very much lie in the functional revolution espoused by Sadr and others, and it is hard to see how Islamic finance could retain its legitimacy if it were to abandon these objectives altogether. In that case, Islam would not be articulating a space within which forms of human association were more mutual, communitarian, humane, and just. Rather, Islam would be slavishly following the functional objectives of financiers and commercial actors everywhere and using its energies to ensure that whatever objectives were articulated by them were suitably adjusted in form to serve the Langdellian modalities. This would be entirely inconsistent with the oft-heard Muslim cliché that Islam represents "a comprehensive and all-encompassing code of life."204 Under the Langdellian hermeneutic, Islam would not be a code or way of life but an annoying externality to be minimized and a trivial obstacle to be circumvented after all of the important decisions concerning ethics and ideal types of human association and social organizations have been made. Whether this could survive in the long term is highly questionable. It was Sadr's revolution that brought the jurists back from irrelevancy, and the resurgence of Langdellianism seems destined to consign them once again to it.

tuality, supra at 5-7. El-Gamal's work is bold, noteworthy and, as a sophisticated and thoughtful analysis of the necessity of functionalism in Islamic finance, largely unprecedented. El-Gamal's unwillingness as an economist, however, to discuss notions of jurisprudence extensively leaves some noticeable gaps in his ideas. It is one thing to say that mutual structures accord with the "spirit" of the doctrines of riba and gharar more harmoniously than do for profit structures, but it is difficult to see, absent a functional jurisprudence, how such vague notions of "spirit" could translate into doctrine. Given El-Gamal's implicit acceptance of Islamic finance artifice as complying with the letter of shari'a, a bank could just as easily comply with Islamic doctrine by more extensive artifice. Professor El-Gamal rightly notes that such a bank differs so little from a conventional bank that it is difficult to see what purpose it would have, something I have repeated elsewhere in my own work. See Hamoudi, supra note 39, at 616 (suggesting that an openly formalist approach to Islamic finance that fails to articulate broader societal interest could "doom the practice"). But the point is broader than one of mere utility; the difference between a formalist Islamic bank and a functionally distinct financial institution at the doctrinal level must be more sophisticated than that both are equally Islamic but that one merely conforms better to the "spirit" of the shari'a. Surely the jurisprudence needs to reflect and espouse the functionalism implicit in Professor El-Gamal's invocation of the "spirit" of the shari'a in order to serve its purposes effectively and, by so doing, reject the Langdellian formalism that is characteristic of contemporary applications of shari'a.

204. See, e.g., Muhammad Shoaib Omar, Introduction to MUFTI MUHAMMAD TAQI UsMANI, CONTEMPORARY FATAWAA 17 (Muhammad Shoaib Omar ed., 2001). 


\section{B. A Revolution Revised}

Adapting Sadr's revolution in a manner that will permit Islamic finance to serve its central ontological function of an Islamic form of social justice in commercial association requires some alteration at both the political and the institutional levels. Such changes are readily achievable, but do require a significant narrowing of the scope of Sadr's vision from a revolutionary economic sphere of association to more voluntary forms of commercial and financial conduct governed by Islamic rules.

With respect to the political question, Iqtisaduna envisioned some form of juristic political rule to ensure that the forms of human association it proposed would be enacted as binding law. Sadr became more enamored of juristic political rule as time progressed. ${ }^{205}$ He did consider the possibility of a financial institution that operated on Islamic principles in the absence of juristic rule and even devoted a book to this subject. ${ }^{206}$ However, in describing such a bank, which in many ways resembles the Islamic financial institutions that currently operate, he presciently acknowledged that its ability to serve central Islamic objectives would be limited, and he clearly envisioned it as some sort of temporary and limited measure on the road to juristic rule. ${ }^{207}$

There are numerous problems involving juristic rule that this Article can only mention in brief. First, the one example in the Shi'i context is Iran, which, given its substantial problems, seems to be evidence enough of the danger of juristic political rule. ${ }^{208}$ Secondly, some have

205. See Section II.B.3, supra.

206. See generally MUHAMMAD BAQR AL-SADR, AL BANK AL-LA RIBAWI FI’L ISLAM (1973).

207. See id. at 6-7. ("[A]nd this type of limited incremental implementation will not permit the idea behind the prohibition of riba to bear its full fruit, or to serve the same objectives that could be achieved if placed within the comprehensive implementation of the entire Islamic regime.”).

208. Iran's numerous failures on so many fronts are beyond the scope of this Article but some bear mentioning given my endorsement of a Shi'i jurist who played some role in its current legal system. While advocating functionality in jurisprudence and social justice in economic affairs, Sadr barely seems cognizant, given his lack of writings on the subject, of the possibility that his beloved marja'iyya might be corrupted by political rule or otherwise compromised by political realities, which would thereby thwart any economic or social agenda. This is precisely what occurred in Iran, both in terms of economic and financial planning as well as in the elimination of political opponents, even when they might be jurists. See, e.g., NIKKI R. KEDDIE, MODERN IRAN: RoOTS AND RESUltS OF REVOLUTION 256, 262-84 (2003) (economic failures); MALLAT, supra note 5, at 152-57 (land reform failures); RoY, supra note 32, at 138-40 (economic failures); R. James Woolsey, WWIV: Who We're Fighting—and Why, 4 Rich. J. GLOBAL L. \& Bus. 1, 7 (2004) (discussing house arrest of former heir apparent to Khomeini, the jurist Ayatollah Montazeri). In addition, the consequences in Iran of juristic rule were particularly appalling from a 
argued that juristic rule and the imposition of an Islamic legal system is entirely discordant with the notion of the shari'a, which is by its conception broadly diverse and in which competing and inconsistent interpretations exist alongside one another. ${ }^{209}$ Finally, there is the question of practicality. There is nothing to suggest revolutionary transformational appetite among Islamic nations, which have by and large adopted modern, secular commercial codes as their developmental models. ${ }^{210}$ The functional revolution and the constitutional moment sought by Sadr thus require adjustment in a manner that assumes secular political rule and seeks to create, within any particular political entity, voluntary forms of commercial activity operating under functionally reformulated Islamic rules and principles.

human rights perspective given shari'a provisions, unopposed by Sadr, that do not recognize religious freedom for religions other than Islam and certain "protected" faiths, permit child marriage, and render a woman's testimony half the value as that of a man's, all of which found their way into Iranian law. See U.S. DEPT. OF StATE, 2 COUNTRY REPORTS ON HUMAN RigHTS FOR 2005, at 1831-32, 1838-39 (2006), available at http://www.state.gov/g/drl/rls/hrrpt/2005/61688.htm. Respecting women in particular, Sadr hardly fits the cartoonish cliché of a crazed, turbaned misogynist who objects to the presence of women anywhere in the public sphere, given the prominent role his sister Bint al-Huda played in Islamic revivalism with his encouragement. See MALlAT, supra note 5, at 16 (describing Bint al-Huda as leading the "feminist rubric" of the Islamic revival and as a contributor to a Najaf journal edited by Sadr); Aziz, supra note 31, at 210 (describing Sadr's role at the journal); Mottahedeh, Introduction to LESSONS IN ISLAMIC JURISPRUDENCE, supra note 18, at 28, 31 (describing the role of Bint al-Huda before and after Sadr's arrest). Nevertheless, there is no indication that he was in the slightest interested in reforming troublesome areas of the shari'a to ensure broader rights for women. My endorsement of Sadrism must, therefore, be qualified as I share neither Sadr's political views, nor his apparent disinterest in shari'a reform in multiple areas. Still, Sadr's deep and abiding concern with social justice in Islamic economic and financial affairs as well as the functional jurisprudence he employs to achieve this worthy objective are noteworthy and deserving of greater consideration and respect, whatever his other faults may be.

209. Professor An-Na'im discusses this primarily in the context of Sunni jurisprudence, indicating that a State could not, in the exercise of its ordinary political functions, simply enact one of the many available interpretations of shari'a and plausibly declare that one version to be the true Islamic version above all others. See Abdullahi An-Na'im, Shari'a and Positive Legislation: Is an Islamic State Possible or Viable?, in 5 YEARBOOK OF IsLAMIC AND MIDDLE EASTERN LAW 29 (Eugene Cotran \& Chibli Mallat eds., 2000). If this is true with respect to Sunni jurisprudence, it is emphatically more the case with respect to Shi'ism and its plethora of mujtahids with competing interpretations, whose disagreements are the very basis for the informal hierarchy of Usuli Shi'ism. See SADR, supra note 84, at 21 ("If the mujtahids... agree in their opinions and fatwas, then a follower may follow any as he wishes, but this is purely a theoretical assumption which would not happen in actual life normally because ijtihad is most often the occasion for disagreements.”). The breakdown of the historic Shi'i system once political authority is involved can be seen in Iran's implementation of juristic rule, where, rather than compete with others for followers and their financial contributions, reformist jurists have little opportunity to express alternative views and are silenced by the force of the State. See Woolsey, supra note 208, at 7 (providing an example of dissenting views being silenced by Iran).

210. See BERNARD G. WeISS, THE SPIRIT OF ISLAMIC LAW 188 (1998). 
A number of Muslim nations, most notably Malaysia, permit the operation of Islamic financial institutions alongside their more conventional counterparts, ${ }^{211}$ and it is here where functional approaches can most sensibly be tested. These institutions will need to operate within boundaries set by established political authorities. This will prevent the institutions from engaging in entirely transformed types of social and economic interaction. However, this necessary conservatism, whether viewed as the initial step towards broader social transformation, or alternative limited means of living within the substantial ideological and political constraints and assumptions imposed by the type of free market economy whose institutions dominate the earth, should not derogate from the socially desired outcome-an alternative means of voluntary social and economic association developed under Islamic doctrine where notions of mutuality and social justice play as important an institutional role as profit and economic gain.

The second transformation necessary to reform, or rather expand, Sadr's revolutionary functional notions relates to the specific interpretive community charged with the task. Specifically, the applicability of Sadrist functionalism might be somewhat limited if the relevant interpretive community were defined exclusively as the Najaf marja'iyya. Most importantly, Sunni Muslims, who comprise 85\% of the world's Muslims, ${ }^{212}$ recognize no institutional role for the marja'iyya, and their ability to participate in such a revolutionary functional exercise would be limited if predicated on marja'iyya endorsement. Secondly, despite their supposed respect for Sadr, ${ }^{213}$ their fellow mujtahid, it is not clear that the marja'iyya in Najaf are interested in functionalism. My own discussions with clerics in Najaf leave me optimistic about their willingness to permit doctrine to evolve to meet the needs and demands of Muslim society in areas such as commerce and finance. Nevertheless, it is also true that the most prominent member of the Shi'a marja'iyya is currently Ayatollah Ali Sistani, whose works betray a deep and abiding attachment to formalism. ${ }^{214}$

211. WARDE, supra note 195, at 123. This does require some level of cooperation and coordination between religious and political authorities, a matter to which I intend to devote considerably more attention in the future. For purposes of this Article, it is only important to note as an aside that in order for Muslim societies to realize the goals to which their populations aspire respecting such contemporary Islamic ideals as social justice and mutuality in matters of commerce, both political and religious reform will be vitally necessary.

212. Freamon, supra note 90, at 303 n.14.

213. See id. at 347 (noting how the death of Sadr "galvanized the Shi'a ulama in Iraq and Iran”).

214. Sistani is frequently lauded in the United States press for his relatively "quietist" role in 
To the extent that the marja'iyya was less receptive to Sadrist functionalism, Shi'a could instead seek to work through "deviationist” mujtahids who could arise. Whether former students within the Najaf marja'iyya or not, it is possible to imagine a body of Shi'i scholars separating themselves from the Najaf marja'iyya and developing alternative approaches to finance and other areas of the shari'a within a separate institution. The revised revolution could thus begin with something akin to an uprising within Usuli Shi'ism itself by those promulgating this deviationist Islamic doctrine, and the relevant interpretive community could then bind the enterprise with whatever objective limitations it saw fit. The extent to which it took hold within Shi'ism generally would depend entirely on its popularity among the lay Shi'a who supported the deviationist jurists. ${ }^{215}$

For Sunnis, the view is slightly more nuanced and potentially more democratic. There is no notion within Sunni jurisprudence of mujtahids deriving authority as the Hidden Imam's deputies. However, because Sunnism accepts juristic consensus, or ijma, as a source of the shari'a, Sunni jurisprudence has some room to develop functional deviationism on the basis of communal understandings, though it requires a transformed understanding of what ijma might mean. That is, ijma cannot mean, as it currently does in the context of Islamic finance, the fixing of particular applications of qiyas for all times and places by reason of a

political affairs. See, e.g., Thomas L. Friedman, A Nobel for Sistani, N.Y. TIMES, Mar. 20, 2005, § 4, at 13. Too much can be made of this. While it is true that Sistani does not believe in a role for jurists in political affairs in the way that Sadr and Khomeini did, this "quietism" harks back to Usuli Shi'ism's most formalist stages, prior to the appearance of Sadr, when increasingly ignored and irrelevant jurists continued to write tiresome, lengthy risalas about arcane points of Shi'i law, while other secular ideologies such as Marxism took hold over the lay Shi'a imagination. A brief look at Sistani's website will demonstrate the extent to which Sistani is himself captivated by such ruminations. See Sayyid Ali Husaini Sistani, Islamic Laws: Najis Things-Sweat of an Animal Who Persistently Eats Najasat, I 119, http://www.sistani.org/local.php?modules=nav\&nid=2\&bid=59\&pid=2866 (last visited Oct. 10, 2007) (regarding whether the perspiration of a man who engages in sexual intercourse when he should be fasting is ritually impure). This is not to suggest that Sistani's reluctant forays into politics have been less than salutary; commentators are right to credit him as a generally positive force within Iraq. However, to expect from Sistani anything by way of alternative approaches to the shari' $a$, whether they are functionalism in economics or finance or other reformist ideas in the context of women's rights or criminal law, is unrealistic given Sistani's unabashed orthodoxy, of which "quietism" is but one of its many manifestations.

215. Of course, given the nature of Usuli Shi'ism, the development of a deviationist school would be radical and not a step to be taken lightly, as the implication of the move would be that the marja'iyya had strayed to the point that it no longer spoke for the Mahdi, and an alternative institution of authority was needed. 
consensus reached at a particular time. ${ }^{216}$ Instead, the ijma would be fluid, permitting the community to retell its narrative history during seminal moments, emphasizing some values over others and recasting Islamic doctrine to achieve openly ideological and ethical objectives, but doing so in a manner that also binds those charged with interpreting within the newly energized jurisprudence with objective limitations on the interpretive effort. My colleague Professor Freamon introduces something akin to this in his call on largely Sunni jurisprudential grounds for an Islamic ban on slavery based upon Muslim consensus against the practice, notwithstanding the fact that the Qur'an and the hadith, at the very least, presuppose slavery's existence. ${ }^{217}$

Professor Freamon contends something akin to Sadr's deviationism. Freamon emphasizes values of equality that may have lain dormant for centuries in the context of slavery, pointing to a growing and now virtually complete ideological and ethical conviction within Islam against the practice. He seeks a prohibition through a new understanding of Islamic doctrine that tells a compelling historical narrative and is objectively bounded, but is nonetheless, by his admission, changing centuries of understanding concerning the Islamic rules on the practice of slavery. ${ }^{218}$ Largely on the basis of ijma, he ultimately uses Islamic doctrine to achieve a deviationist ideological objective that proscribes, on Islamic grounds, a practice in which some of Muhammad's closest Companions engaged.

A liberalized form of ijma along these lines could be extended to the question of Islamic finance, given the desire of the community to articulate jurisprudence in a manner that would render commerce and financial association as much about fair dealing and social justice as earning money. A community of Sunni Muslims, presumably schooled in Islamic thought, could develop their own deviationist and functional notions of Islamic finance and seek to apply them. They may, indeed they would, need to redevelop Langdellian notions of jurisprudence to achieve this, but there is no reason that they could not seek to do so. This self-designated "deviationist" community could then reorganize financial institutions along functional and self-acknowledged ideological lines by telling its own compelling Sadrist tale of Islamic mutuality and economic justice throughout the ages. Whether this movement

216. See note 60 and accompanying text, supra.

217. See Bernard K. Freamon, Slavery, Freedom and the Doctrine of Consensus in Islamic Jurisprudence, 11 HARV. HuM. RTS. J. 1 (1998).

218. See id. at 28-29. 
would remain an isolated, deviationist tribe or result in a new understanding of Sunni jurisprudence would depend entirely on the popularity of the idea within the Sunni community. If functional financial institutions were to take hold and dominate the community, I could then argue, using Professor Freamon's ideas, that the understanding of what riba and gharar were intended to encompass had shifted, and a different understanding was required, sanctified through ijma. In the absence of such unanimity of Sunni belief, the deviationist movement could continue as long as it had sufficient support to sustain it.

Thus, the absence of a defined community like the marja'iyya would make the determination of an ijma more problematic in the Sunni context, but, as Professor Freamon's example shows in the context of slavery, hardly impossible. Sadr's ideological and functional deviationism could thus survive the failures of the political revolution within the Sunni and Shi'i communities alike.

\section{REFORMED SADRISM IN APPLICATION}

I have elsewhere provided primitive examples of doctrinal mechanics using ideas promulgated by Sanhuri, Sadr, and others that would allow for functionalism in reformulating the doctrines of riba and gharar to achieve the communal expectations of mutuality and social justice in a more practicable manner than Sadr may have envisioned. ${ }^{219}$ It is not my purpose to repeat those here, primarily because the focus of this Article is less on the economic principles underlying the communal expectations and more on the jurisprudential ideas necessary to sustain them. Suffice it to say that it is not difficult to develop doctrine that is consistent with foundational text, meets communal expectations by emphasizing or favoring mutuality in most economic transactions, prohibit highly exploitative and lucrative gain, and ban excessive speculation. The greater challenge will be in ensuring commercial practicability, a matter that can only be tested experientially.

Therefore, rather than repeat the mechanical exercise, I demonstrate the potential relevance of functionalism in Islamic finance to the broader financial world by indicating the extent to which it could engage the global financial community on topics of contemporary importance. I have selected as an example one such topic that has been discussed with varying degrees of interest over the past two decades; namely, the extent to which a commercial bank should engage in activi- 
ties commonly attributed to other financial services institutions such as investment banks. ${ }^{220}$ These activities would include the underwriting of securities, the purchase and sale of securities, the ownership of equity interests in non-financial firms, and the offering of money market mutual funds wherein customers open accounts that are invested in highly liquid, low risk and low return securities from which they can withdraw relatively freely. I summarize the issue first and follow with a discussion of the manner in which issues like this are entirely divorced from the realities of the formalist practice of Islamic finance, whereas an alternative, deviationist Islamic model based on functional notions could potentially contribute ideas and practices to the global discussion that may prove helpful.

\section{A. Debate over Universal Banking}

Much of the discourse in the United States concerning the wisdom of permitting a single financial institution to engage in both traditional banking activities and investment banking activities has dissipated with the passage of the Gramm-Leach-Bliley Act in 1999, which permits investment banking firms and commercial banks to be affiliates of one another under an umbrella holding company. ${ }^{221}$ This repealed the Depression Era Glass-Steagall Act, which had forbidden such associations, ${ }^{222}$ and with it, the United States joined most other developed nations in either permitting affiliations between commercial and investment banks or, in the case of some nations such as Germany, allowing a single unified financial institution to engage in both activities. ${ }^{223}$ Nevertheless, the issue retains some importance because not all

220. In some sense, my example is fanciful because Islamic functionalism in finance would most likely begin with the type of small institutions taking a mutual structure envisaged by Professor El-Gamal, see supra note 203, rather than anything with the size necessary to engage seriously both in conventional banking and the purchase and sale of securities. Nevertheless, the point is not so much whether large functional institutions are imminent, but rather that functional institutions of any size would, to varying extents, contribute to the global conversation about commercial and economic order in the contemporary era.

221. See Gramm-Leach-Bliley Act, Pub. L. No. 106-102, 113 Stat. 1999 (repealing Sections 20 and 32 of the Glass-Steagall Act (codified in 12 U.S.C. §§ 78, 377)); see also Jonathan R. Macey, The Business of Banking: Before and After Gramm-Leach-Bliley, 25 J. CORP. L. 691, 709, 715-16 (2000).

222. Macey, supra note 221, at 691.

223. See George J. Benston, Universal Banking, 8 J. ECON. PERSP. 121 (1994) (discussing Germany and Canada); Brian Arthur Pomper, The Japanese Financial Reform of 1993: Will Reform Spark Innovation?, 28 CORNELL INT'L L.J. 525, 525-29 (1995) (discussing Japan). 
nations have followed the recent trend; China, for example, continues to forbid its banks from operating in the stock market. ${ }^{224}$

The reasons for and against such mergers have been extensively discussed in the academic literature. The most prominent reasons against permitting financial institutions to engage both in commercial and investment banking inevitably relate to bank instability and potential conflicts of interest. The argument is that the banks might take risks that would lead to losses, and consequently, a bank run. ${ }^{225}$ For example, two scholars have maintained that banks in Germany often lend to businesses that they expect will be able to repay such loans through issuances in the stock market, making them particularly vulnerable to market fluctuations. ${ }^{226}$ Risks could also be amplified if the bank were to make loans to firms in which the bank had a significant investment that were not performing well even if this was against the interests of depositors. ${ }^{227}$ Moreover, the larger the bank, the more likely that it would operate under the belief that it was simply "too big to fail," which would by itself encourage excessive risk taking. ${ }^{228}$

Critics also contend that banks' perverse incentives will hamper the efficient operation of a proper stock market and stock market prices will be distorted by bank interference. ${ }^{229}$ China banned commercial banks from investing in the securities markets in order to prevent incidences of overspeculation that occurred prior to the ban. ${ }^{230}$ Others have concerns that relate to the potential for monopolistic behavior, whether it be the reduction of consumer choice, the crowding out of smaller financial institutions, or an unhealthy concentration of power. ${ }^{231}$

In the context of banks seeking to offer clients money market mutual funds, other issues could arise. For example, as investments in these funds surely would not be considered equivalent to a bank deposit for regulatory purposes, they probably would not be counted toward any

224. Yuwa Wei, The Development of the Securities Market and Regulation in China, 27 LOY. L.A. INT'L \& COMP. L. REV. 479, 509 (2005).

225. See id. at 511-12.

226. See HANS-HERMANN FRANCKE \& MiCHAEL HudSON, BANKING AND FINANCE IN WEST GERMANY 7 (1984).

227. Wei, supra note 224, at 512 .

228. See Benston, supra note 223, at 123-24 (discussing and ultimately dismissing this position).

229. See id. at 127-28.

230. Amy Chunyan Wu, $P R C$ 's Commercial Banking System: Is Universal Banking a Better Model?, 37 COLUM. J. TRANSNAT'L L. 623, 628, 632-633 (1999) (ultimately concluding that the ban was unnecessary and that a universal banking model would serve China well).

231. See Benston, supra note 223, at 131-38. 
premium against which banks were required to insure their investments, nor would they count toward any reserve requirements a bank was required to maintain. ${ }^{232}$ Given these factors and the superficial similarity of such money market funds to bank deposits, banks might prefer to encourage purchases of the former as against the latter. This does raise concerns, however, given that the money market accounts have more risk associated with them and because banks might not be the most appropriate vehicles to offer them, due to their strong association with a similar but safer form of deposit. ${ }^{233}$

There are several arguments in favor of the universal banking model as well. Supporters of the merging of investment banks with universal banks argue that the new institutions are more broadly diversified and therefore more stable. ${ }^{234}$ In addition, there are potential synergies to be gained from a combination of the two practices into one firm due to the similar lines of business and overlapping client bases. ${ }^{235}$ This could also permit universal banks to be more effective at restructuring troubled firms because they could hold both the firm's outstanding loans and a significant portion of its outstanding securities. ${ }^{236}$ More broadly, if banks held equity interests in the companies to which they loaned money, they would be better and more efficiently able to monitor and control the loans they had offered. ${ }^{237}$ Finally, there is an argument that the development of fewer and more concentrated institutions in the fi-

232. See, e.g., Jonathan R. Macey \& Geoffrey P. Miller, Nondeposit Deposits and the Future of Bank Regulation, 91 MiCH. L. REV. 237, 267-71 (1992).

233. Much of this relates to whether banks are "special" institutions worthy of special treatment and regulation, or whether they should be regarded no differently than other financial institutions. This is a matter that has also received a great deal of attention in the academic literature. Compare Structure and Regulation of Financial Firms and Holding Companies Before the Subcomm. on Commerce, Consumer and Monetary Affairs of the H. Comm. on Government Operations, 99th Cong. 121, 134-135 (1986) (statement of Paul A. Volcker, Chairman, Board of Governors of the Federal Reserve System) (describing unique role banks play within the American economy), with Richard C. Aspinwall, On the "Specialness" of Banking, IsSUES IN BANK. REG., Autumn 1983, at 16-17 (suggesting there is nothing so special about banks that requires special regulation for them). If one assumes banks to be special financial intermediaries with unique characteristics, then there could be reason to prevent them from offering instruments that resemble deposits but are uninsured and do not have reserves placed against them. This position carries considerably less force if banks are not considered to be special actors within the commercial system.

234. See Benston, supra note 223, at 126; Macey, supra note 221, at 720; Jonathan R. Macey et al., The Glass-Steagall Act and the Riskiness of Financial Intermediaries, 14 RES. L. \& ECON. 19, 21, 25 (1991).

235. Jonathan R. Macey, The Inevitability of Universal Banking, 19 BROOK. J. INT'L L. 203, 214-16 (1993).

236. Benston, supra note 223, at 129.

237. Id. 
nancial services sector would reduce regulatory costs, though, at least in jurisdictions such as the United States, such a benefit is not clear. The Gramm-Leach-Bliley Act did not seem to reduce the level of oversight or the number of governmental bodies responsible for banking regulation; several regulatory bodies continue to exercise oversight over any given financial holding company. ${ }^{238}$

\section{B. Islamic Reverberations}

The most obvious conclusion to be drawn from even a cursory evaluation of the above concerns is their considerable distance from anything within the frame of reference of contemporary Islamic finance. As developed under the Langdellian hermeneutic, Islamic finance could add nothing to the debate simply because it claims not to be engaged in the practice of offering debt in the way that a conventional bank does; it claims instead to be operating already as a mutual fund, with the funds of its "investors" taking part in the purchase and sale of "assets" through the murabaha and "profits" being shared between the institution and the "investors" as they would be in a mutual fund. ${ }^{239}$ Islamic banks could not continue to indulge this fantasy and seriously enter the debate over universal banking. Therefore, any developing Muslim nation attempting to decide whether it is better in its particular context to separate commercial banking activities from investment banking activities, permit affiliations as in the United States or even promote the existence of single unified entities as in Germany would not look to Islam in its formalist manifestation to answer this question.

By contrast, it is striking to note how relevant functional Islamic doctrine potentially could be in contributing to a debate on this issue. So many of the areas of debate, whether they relate to the risk of bank failures, the concerns of excessive speculation on the part of banks, the potential for limitations on consumer choice or the possibility of a conflict that works to a client's detriment and the bank's gain, directly implicate notions of mutuality of interest, exploitation, unfairness, social justice, speculation, and excessive uncertainty that could form the backbone of a functionally reformulated doctrine of riba and gharar. ${ }^{240}$ Islamic

238. Macey, supra note 221, at 710-13 (describing the "functional" system put forward by Gramm-Leach-Bliley).

239. See El-Gamal, supra note 3, at 126-28 (describing profit sharing claims of Islamic banks).

240. This is not to suggest that riba and gharar would be the sole components of a reformulated functional jurisprudence; clearly other Islamic doctrinal concepts could play a role. See S.E. RAYNER, THE THEORY OF CONTRACTS IN ISLAMIC LAW 204-55 (1991) (discussing Islamic 
banks could influence the decisions of Muslim societies with respect to the question of universal banks and, in any event, the banks could make their own independent decisions concerning their entry into securities markets to the extent that these decisions do not conflict with national law.

Regardless of the decision a bank makes respecting universalization, it would be part of the evolution of the financial system. If Islamic banks were to deem universal banking to be permissible, they could act as experimental models for nations that were interested in determining the suitability of universal banks more broadly. By contrast, if Islamic banks felt that the universal banks contravened functionally derived Islamic prohibitions, a Muslim nation could permit general entry of banks into securities markets and compare the performance of those banks that did enter with the performance of similarly situated Islamic banks that did not. In either of these cases, Islamic financial institutions would be contributing to a healthier economic polity, deeply relevant to fundamental questions concerning commerce and finance, and more effectively serving the goals that the original creators of Islamic finance articulated: fairness and social justice in a unique Islamic context.

\section{CONCLUSION}

The existential problem facing Islamic finance seems clear. From the standpoint of determining the ideal means of organizing society, the practice is entirely irrelevant given its deep and abiding attachment to an interpretive hermeneutic akin to Langdellianism. This is entirely inconsistent with the notions of its founders and many of its current adherents who expect it to offer to Muslims an alternative, fairer, more mutual and more humane system of economic order.

The ideas of economic revolution developed by one of Islam's most influential modern jurists, Muhammad Baqir al-Sadr, betray an astonishing level of functionalism in which Islamic doctrine is explicitly developed on the basis of subjective political, ideological, and ethical presuppositions and is designed precisely to achieve these mutuality and social justice objectives. Unlike the critical legal theorist, however, Sadr does not argue that all doctrine is subjective, but that subjectivity is inevitably part of the interpretive process. Sadr's notions presuppose the

commercial prohibitions akin to exploitation, fraud, and duress). I make exclusive reference to the most commonly cited prohibitions of riba and gharar, however, in the interests of simplicity and space. 
existence of an institution, the marja'iyya, which is entrusted with the theological authority to redefine the shari'a on ideological and ethical bases, and then subsequently to constrain individual jurists as well as the ordinary lawmaking process with external and objective disciplining rules so as to ensure an objective and neutral role for the shari'a in rulemaking. Despite certain flaws in his ideas, and, in particular, Sadr's association of the political with the economic under a single revolutionary Islamic rubric, Sadr's radical blend of objectivist and subjectivist jurisprudence can play an important role today in rescuing Islamic finance from increasingly silly Langdellianism in order to permit Islamic finance to contribute to developments in global banking in a manner that retains its faithfulness to its populist, mutualist, and deeply Islamic roots. 